Working Paper Number 168

\title{
Anti-Corruption Law in Local Government: Legal Issues related to Ordinance-Design and Municipal-Level Anti-Corruption Agencies in Macedonia
}

\author{
Bryane Michael, Linacre College (Oxford) and \\ Stephen Mendes, European Border Assistance Mission to Moldova and \\ Ukraine (EUBAM)
}

Introduction

Municipal Government in Macedonia and Legislative Anti-Corruption Provisions

Covering Municipal Bodies

Particularities of Anti-Corruption Municipal Government Law ......................................... 5

The Reasons for and Structure of Anti-Corruption Agencies for Municipal Authorities .. 19

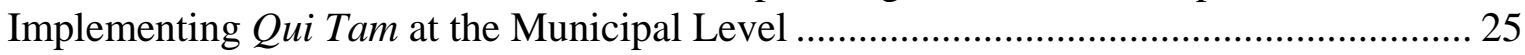

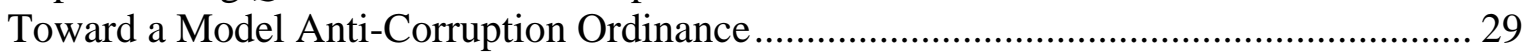

Conclusions and Future Research Questions ............................................................. 35

Macedonian municipalities should pass anti-corruption ordinances in order to reduce corruption. The paper reviews the legal issues involved in drafting such ordinances and provides legal advisors to local councils with the legal and economic analysis needed to tackle some of the more difficult and detailed questions. The most important issue revolves around the creation of a model ordinance which Macedonian municipalities (or the Association of Units of Local Self-Government of the Republic of Macedonia) could adopt in order to set-up and run municipal-level anti-corruption agencies. The location of such agencies as well as their competencies (to monitor conflicts of interests, oversee asset declarations, and conduct corruption risk-audits among others ) are analysed. The paper also provides legal interpretations of Macedonian legislation and their likely impact on municipal council ordinance design in the area of anti-corruption -- providing the legal basis for positive administrative silence, the splitting of municipal procurement contracts, and (most controversially) qui tam rewards at the municipal level. A brief regulatory impact analysis of the ordinance shows a gain of $€ 162,900$ in social welfare if such a programme were rolled-out in Macedonia.

September 2008 


\title{
Anti-Corruption Law in Local Government: Legal Issues related to Ordinance- Design and Municipal-Level Anti-Corruption Agencies in Macedonia ${ }^{1}$
}

\author{
Bryane Michael, Linacre College (Oxford) and
}

Stephen Mendes, European Border Assistance Mission to Moldova and Ukraine (EUBAM)

\section{Introduction}

For the last decade, a large number of anti-corruption programmes have focused on the local or city level. During this decade, Ronald Mac-Lean's case study of La Paz's anticorruption programme served as the model for anti-corruption strategies around the world and at every level of government. ${ }^{2}$ Many powerful arguments point to the need to create local-level anti-corruption programmes - particularly in Macedonia. First, much local service provision - where corruption is most prevalent -- occurs at the municipal level. ${ }^{3}$ Second, the EU-wide decentralisation trend makes focusing on sub-national government more important; and Macedonia's recent decentralisation programme provides many opportunities for corruption at the municipal level. Third, Macedonia represents an ethnically diverse nation - making municipal-level policy preferences at times very different than national level ones. As such, the optimal level for anti-corruption lawmaking in Macedonia could well be at the local instead of the national level. However, most local anti-corruption programmes proceed with little or no legal analysis - with local and international experts simply organising "stakeholder meetings" and "action plans" having no legal basis. ${ }^{4}$ The present paper hopes to provide some of the legal analysis which these previous papers lack.

Macedonian municipalities should pass anti-corruption ordinances in order to reduce corruption. This paper reviews the legal issues involved in the drafting of such ordinances - particularly in relation to the establishment and functioning of municipal-

\footnotetext{
${ }^{1}$ For the purposes of this paper, we refer to the internationally recognised name of the Former Yugoslav Republic of Macedonia (and the internally recognised name of the Republic of Macedonia) simply as Macedonia. We use the simple name Macedonia on the grounds of simplicity. Our reference does not imply a political association related to the country's name (and as technocrats, we have no personal views on the country's name). As a contribution to the liberal academic tradition, the ideas in this paper reflect our views and opinions and do not impact or reflect any policy advice we may provide in any non-academic capacity. ${ }^{2}$ See Robert Klitgaard, Ronald MacLean-Abaroa and H. Lindsey Parris, A Practical Approach To Dealing With Municipal Malfeasance, UNDP/UNCHS/World Bank-UMP Conference Paper (1998), available online. The impact of these authors' subsequent book Corrupt Cities can not be over-estimated -- as the "action planning" and "stakeholder involvement" concepts evoked in their work have served as the basis for most World Bank and USAID anti-corruption programmes targeting the sub-national (and even national!) level. In 2008, the UNDP-Moldova's tender for training in local anti-corruption contractually required bidders to demonstrate specific knowledge of Corrupt Cities and follow the strategies contained within. ${ }^{3}$ See Daniel Kaufmann, Judith Montoriol-Garriga, and Francesca Recanatini, How Does Bribery Affect Public Service Delivery? Micro-Evidence from Service Users and Public Officials in Peru, WoRLD BANK POL. RESEARCH WORKING PAPER No. 4492, 2008, available online. Macedonia particularly represents a mystery as only $17 \%$ of public service users reported in a 2006 survey to having paid a bribe in the previous 5 years. See SAints Cyril And Methodius University of SKOPJE, Public Opinion On CORRUPTION IN THE REPUBLIC OF MACEDONIA, Available online. The apparent contradiction between the high levels internationally of municipal-level corruption and low levels in Macedonia may be explained by the relative newness of Macedonia’s decentralisation programme.

${ }^{4}$ Municipal-level anti-corruption programmes have been heavily supported by the World Bank and USAID. As an example of the unholy alliance between the World Bank and USAID in the area of decentralisation and anti-corruption, see the USAID policy brief hosted on the World Bank website, Robert W. Rafuse, Jr., Why Fiscal Decentralization in Macedonia? Available online.
} 
level anti-corruption agencies (as defined later in this paper). ${ }^{5}$ The first section of this paper briefly covers municipal government structure in Macedonia and reviews the anticorruption legislative provisions which cover Macedonian municipal officials. The second section discusses legal issues related to the main causes of municipal corruption: monopoly power, regulatory discretion and lack of accountability. The third section argues for the creation of three municipal-level anti-corruption agencies (as defined in this paper), provides the legal basis for their creation, and discusses the optimal "location" of these agencies. The fourth section provides the legal basis for ordinance-based qui tam rewards given at the municipal-level - rewards which these agencies can recommend in order to facilitate their own work. The fifth section provides the outlines of a model ordinance which Macedonian municipalities individually (or collectively through a forum such as the Association of Units of Local Self-Government or ZELS) could adopt in order to establish and provide the legal competencies to these municipal-level anti-corruption agencies. The final section providing concluding thoughts and unanswered questions for further research.

\section{Municipal Government in Macedonia and Legislative Anti-Corruption Provisions Covering Municipal Bodies}

At present, Macedonia has 84 municipal governments of varying sizes - with Skopje (the administrative capitol) being both the richest and most populous city. ${ }^{6}$ Figure 1 shows data about these municipal governments grouped into areas. ${ }^{7}$ As shown in Figure 1 , the average citizen of Skopje earns about $\$ 12,000$ whereas the citizen in the Northeast region will earn about $\$ 4,000$ per year. Unsurprisingly, the distribution of municipal revenues and expenditures follows the same trends as the population and GDP per capita figures (as shown in Figure 2) - with Skopje accounting for over 20\% of the country's government revenue and expenditure. ${ }^{8}$ Data on municipal level expenditures (and revenues) provide some insight into municipal-level corruption risks (as presumably more affluent municipalities put more public money at risk through higher volumes of expenditure and offer greater temptations to collect bribes from the higher revenue base). ${ }^{9}$ As discussed later, local ordinances should take the relative degree of corruption risk into account.

\footnotetext{
${ }^{5}$ Thoughout the paper, we use the word ordinance (the US term) instead of by-law (which is usually the term used throughout the Commonwealth) in order to prevent confusion about the level of legal analysis being discussed and to prevent possible confusion in the Macedonian language version of the paper.

${ }^{6}$ Most Macedonian legal texts (following the Law on Local Self-Government) refer to municipalities as "units of local self-government." Article 2 of the Law notes that "units of local self-government are: the municipalities and the City of Skopje.” Throughout this text, we refer to these units of local self-government as municipalities. See Law on Local Self-Government, Official Gazette No. 52/95, available online [hereinafter Local Government Law].

${ }^{7}$ Macedonian law only establishes two tiers of government (national and municipal). Janeska et al. presumably use the groupings of municipalities shown in Figures 1 and 2 to reduce the complexity of their data. VERICA JANESKA, ANICA DRAGOVIC, ILO TRAJKOVSKI, DimitAR BOGOV AND ALEKSANDAR IVANOVSKI. DATA AND INDICATORS OF THE MUNICIPALITIES IN MACEDONIA (2006). available online. ${ }^{8}$ The close tie between municipal level revenues and expenditures signifies the lack of central transfers between regions.

${ }^{9}$ In theory, total corruption risk can be described as the probability (for each municipality) of that municipality's revenue being subject to theft or under-collection due to corruption. The collection of these 84 individual municipality estimates comprises the corruption risk for national municipal-level revenue. In order to arrive at the estimated value of corruption involving Macedonian municipal revenues requires multiplying the corruption risk for each of the municipalities by the municipalities' yearly revenue -- and then summing these 84 estimates to arrive at a national estimate. For more, see Bryane Michael and Mariya Polner, Fighting Corruption on the Transdnistrian Border: Lessons from Failed and Successful AntiCorruption Programmes, TRANS. STUD. REV. (forthcoming), available online.
} 

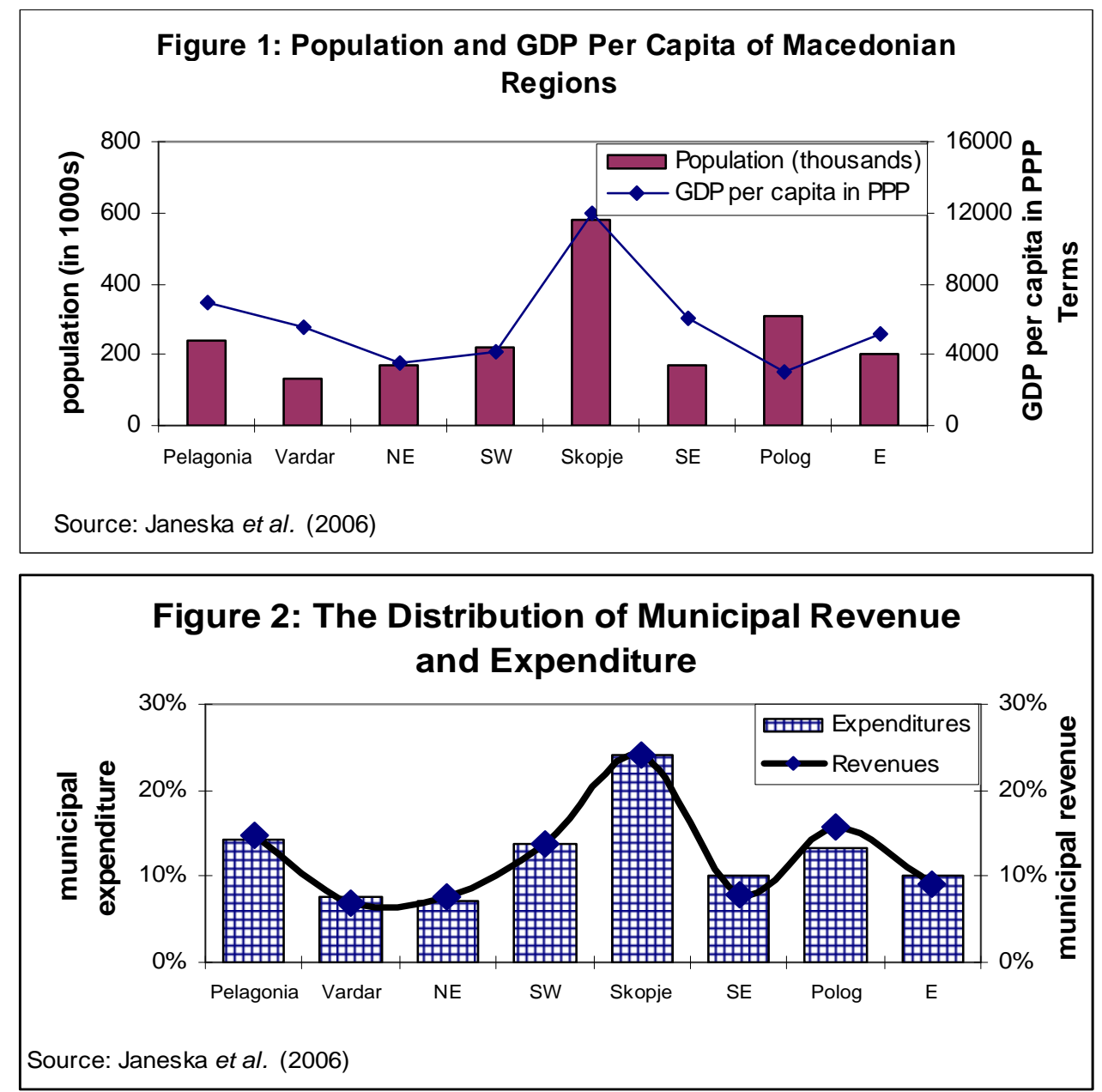

The types of services which local governments provide stem from "home rule" provisions outlined in the national Constitution and the legislation related to local government. The 1992 Local Government Law defines a number of areas of service provision, which Figure 3summarises. To finance these services, Macedonian municipal governments principally collect real estate taxes. ${ }^{10}$

\section{Figure 3: Selected Services Provided by Macedonian Municipal Government}

\begin{tabular}{|l|l|l|}
\hline Unique jurisdiction (article 17 of Local Government Law) & \\
\hline $\begin{array}{l}\text { determine and regulate building } \\
\text { zones }\end{array}$ & garbage collection & $\begin{array}{l}\text { top up funding for primary } \\
\text { schools }\end{array}$ \\
\hline $\begin{array}{l}\text { name and maintain local roads } \\
\text { and streets }\end{array}$ & $\begin{array}{l}\text { regulate and organise public } \\
\text { lighting }\end{array}$ & establish secondary schools \\
\hline supervise drinking water supply & $\begin{array}{l}\text { maintain parks, green areas and } \\
\text { public cemeteries }\end{array}$ & ensure environmental protection \\
\hline tourism promotion & develop civil society networks & regulate public parking \\
\hline provide for rainwater drainage & oversee local transportation & $\begin{array}{l}\text { regulate and organise street } \\
\text { cleaning }\end{array}$ \\
\hline organise and regulate sewerage & maintenance and use of markets & \\
\hline Shared jurisdiction (article 18 of Local Government Law) \\
\hline urban planning & $\begin{array}{l}\text { provide social security and child } \\
\text { care }\end{array}$ & provide basic health care \\
\hline & sponsor sporting events & sponsor cultural events \\
\hline
\end{tabular}

\footnotetext{
${ }^{10}$ Article 17(1) of the Local Government Law refers only to real estate taxes as a method of municipal finance.
} 
Source: Ilija (1994) and articles 17 and 18 of the Law on Local Self-Government. ${ }^{11}$

Municipal governments have the same mandate for fighting corruption as all government entities. ${ }^{12}$ They must uphold the national law - being the subjects of national legislation -- such as the Law on the Prevention of Corruption (hereinafter the AntiCorruption Law), the Law on the Prevention of Conflicts of Interest (hereinafter the Conflict of Interest Law), and other laws - as summarised in Figure 4. Like the central authorities, municipal government agents (as both individuals and as representatives of their employers as legal persons) can be defendants in criminal, civil and administrative prosecutions (and thus are bound by the Macedonian criminal and civil codes as well as the Law on Misdemeanours). Municipal authorities must also comply with the provisions of a number of pieces of legislation which indirectly impact on corruption through their effects on public accountability and public sector transparency - notably the Law on Free Access to Information of a Public Character (hereinafter the Freedom of Information Law) and the Law on Public Procurement. Municipal authorities (as legal persons) must also comply with the Law on Internal Audit. ${ }^{13}$

\section{Particularities of Anti-Corruption Municipal Government Law}

Municipalities differ from central level agencies in several important respects requiring additional anti-corruption measures to be put in place. ${ }^{14}$ First, municipal expenditure accounts for a relatively high proportion of GDP (through public service provision) with the potential problems of market power which bedevil any market. Second, as one of the raisons d'etre of municipal government consists of tying more closely service provision to local needs, local officials exercise greater discretion (as given by regulators and/or local councils). Third, local governments, unlike central government ministries, are (in theory) more accountable to the electorate -- because municipal officials are directly elected by their neighbours and community members. Each of these three elements - namely the potential for monopoly power, the exercise of discretion by public officials, and local political accountability - impact on local corruption. As a heuristic, the anti-corruption literature often cites "Klitgaard’s formula” as corruption (C) equals monopoly power (M) plus discretion (D) minus accountability (A) or of C=M+D-A. ${ }^{15}$

\footnotetext{
${ }^{11}$ See Ilija Todorovski, MACEDONIA, available online.

${ }^{12}$ For a verbose overview of the broader issues and institutional history of recent anti-corruption reforms in Macedonia, see NedA KorunovsKa And DANCE DANILOvSKA, MacEDONIA AND THE CORRUPTION SITUATION AND CHALLENGES (2004). Available online.

${ }^{13}$ In addition, municipalities have additional competencies for fighting corruption as defined in the legislation related to Macedonian decentralisation policy - particularly in the area of the "strengthening of oversight.” See Ministry of LOCAL SElF-GovernANCE, PROGRAMME FOR THE IMPLEMENTATION OF THE DeCEntralisation Process. Available online. For a recent review of the issues, see OECD, Republic of Macedonia Decentralisation Process, available online.

${ }^{14}$ Many of the issues covered in this section derive from Pranab Bardhan and Dilip Mookherjee, Decentralization, Corruption And Government Accountability: An Overview, in SuSAN ROSE-ACKERMAN, HANDBOOK OF ECONOMIC CORRUPTION. The chapter is also available online.

${ }^{15}$ See Robert Klitgaard et al., supra note 2.
} 


\section{Figure 4: Legislative Anti-Corruption Provisions Applicable to Municipal Authorities}

\begin{tabular}{|c|c|}
\hline Legislation & Provisions \\
\hline $\begin{array}{l}\text { Law on the Prevention of } \\
\text { Corruption }\end{array}$ & $\begin{array}{l}\text { Defines a long, specific list of possible areas of corrupt activity, potential } \\
\text { conflicts of interest and establishes the State Commission for the Prevention of } \\
\text { Corruption (the State Commission). }\end{array}$ \\
\hline $\begin{array}{l}\text { Law on Conflict of } \\
\text { Interests }\end{array}$ & $\begin{array}{l}\text { Outlines requirements for declaring interests and the methods the State } \\
\text { Commission uses for checking those interests. }\end{array}$ \\
\hline $\begin{array}{l}\text { Freedom of Information } \\
\text { Law }^{18}\end{array}$ & $\begin{array}{l}\text { Establishes a list of entities from which private individuals can obtain } \\
\text { information, the official procedures for obtaining information and creates the } \\
\text { (succinctly named) Commission for the Protection of the Right to Free Access } \\
\text { to Information of a Public Character. }\end{array}$ \\
\hline Law on Civil Servants ${ }^{19}$ & $\begin{array}{l}\text { Establishes the legal definition of civil servants and individuals covered under } \\
\text { related legislation. Articles } 18 \text { and } 19 \text { specifically address work discipline. }\end{array}$ \\
\hline Criminal Code ${ }^{20}$ & Revisions to the Criminal Code make bribery a criminal offence \\
\hline Law on Misdemeanours ${ }^{21}$ & $\begin{array}{l}\text { Revisions to the Law on Misdemeanours allows for a broader range of } \\
\text { punishments for corruption offences. }\end{array}$ \\
\hline Law on Ombudsman & $\begin{array}{l}\text { Creates a toothless entity whose only function is to appeal to the public and } \\
\text { parliament. }\end{array}$ \\
\hline Public Procurement Law ${ }^{22}$ & $\begin{array}{l}\text { Modern law which establishes the same tender procedures used in other } \\
\text { countries to reduce corruption. Requires competitive bidding for contracts over } \\
€ 500 \text {. }\end{array}$ \\
\hline Law on Internal Audit & $\begin{array}{l}\text { Allows for compliance and performance audit which allows public institutions } \\
\text { (including municipal governments) to discover inefficiencies that may point to } \\
\text { corruption. }\end{array}$ \\
\hline
\end{tabular}

Source: authors.

Public procurements comprise the main area of corruption risk for municipal government. Local government officials are thought to exercise monopoly power over the provision of public services. Municipalities deal primarily in the provision of goods traditionally thought to be public goods - namely goods that private companies do not have the incentive to provide. ${ }^{23}$ Such goods providers are frequently monopoly providers in their markets (and thus generating "rents" frequently referred to in the corruption literature). In Macedonia, according to Figure 5, these procurements totalled a bit less than $€ 50$ million - comprising about $25 \%$ of the value of procurements for state-owned

\footnotetext{
${ }^{16}$ Law on the Prevention of Corruption (2002), available online [hereinafter Anti-Corruption Law]. The 2002 Law (as amended in 2004) does not explicit define the groups of individuals covered by the Law except for Article 2 which covers "[individuals] which [use their] function, public authorization, official duty and position for the purpose to gain any benefit for oneself or for other person.” Rather unhelpfully, Article 8(1) notes that "for determining the meaning of terms, such as elected or appointed functionary, public official, legal entity, responsible person in [a] legal entity and [a] person exercising matters of public interest, the provisions of the Criminal Code concerning [the] meaning of terms shall apply.”

${ }^{17}$ Law on Conflict of Interests, available online.

${ }^{18}$ Law on Free Access to Information of a Public Character (2006), available online.

${ }^{19}$ Law on Civil Servants, available online.

${ }^{20}$ Criminal Code, available online.

${ }^{21}$ Law on Misdemeanor, available online.

${ }^{22}$ Public Procurement Law (2008), available online.

${ }^{23}$ The law only vague refers to the definition or regulation of public goods anywhere in the world. Public goods, as defined in economics, are non-rival and non-excludible. Consequently, their provision requires either collective or monopoly provision -- as no one individual or entity will have the economic incentive to provide them. Many such public goods ostensibly result in natural monopolies which, under certain circumstances, result in rents which government officials may seek to appropriate. Clearly, limits on market access also generate such rents (and remedies for such rent-seeking behaviour are partly addressed in the public procurement law as discussed subsequently in this paper).
} 
enterprises and about half the value of the central agencies. In order to reduce monopoly power in Macedonia, two laws govern municipalities - the public procurement law and the law on the protection of competition. Yet, these two laws only provide a minimum framework - requiring additional ordinance-based provisions aimed at preventing corruption.

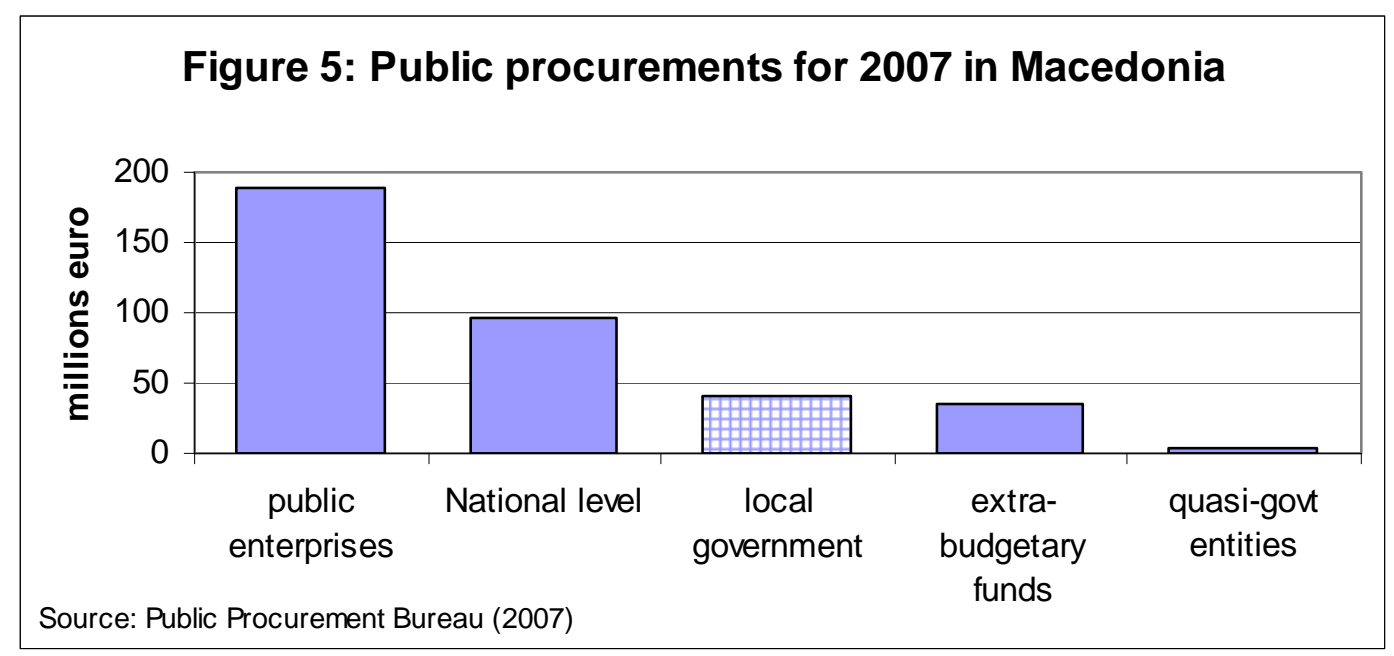

The public procurement law requires additional support from municipal ordinancemaking in order to help reduce the probability of corruption in municipal-level public procurement. First, the procurement commissions hold too much unaccountable power. According to the Law on Public Procurement, municipal governments have the right to establish their own procurement commissions and appoint at their own pleasure the type and number of commission members. ${ }^{24}$ The Law on Public Procurement itself provides few safeguards against bidders "getting to" the members of the commission - a large corruption risk particularly given a small country where “everyone knows everyone.”25 Moreover, the public procurement law does not provide a mechanism of oversight over these commissions or the public procurement system in general. The Public Procurement Bureau possesses competencies more akin to a think-tank than a regulatory and enforcement body. Indeed, from its annual report, the number of submission of PPR-1 Registry forms (which inform the Public Procurement Bureau about a procurement conducted by a state agency) appears to depend on mostly on voluntary compliance by state agencies to submit these forms. ${ }^{26}$ The Public Procurement Bureau further notes that negotiated procedure tenders (requiring no public announcement of the tender) increased by $50 \%$ from 2006 to $2007 .{ }^{27}$

\footnotetext{
${ }^{24}$ Specifically, Article 28(2) of the Public Procurement Law notes that "the decision [to award a public tender] shall [describe] the subject (type) and quantities required, the amount and source of funds required to execute the contract, the manner and the procedure for awarding the public contract and appoint the chairman and members of the procurement commission (hereinafter: the commission), their number and deputies, as well as possible external experts to be hired, if necessary" [italics mine, changes made to the original text to improve clarity of the English language translation].

${ }^{25}$ Moreover, the punishments apportioned by the Macedonian legislation are extremely weak. The Conflict of Interest Law only provides for the dismissal of the public procurement commission member who has been found colluding with a bidder while - if the person could be charged with corruption - would receive a fine of between $€ 333$ and $€ 833$.

${ }^{26}$ Public Procurement Bureau, Report on the Public Procurement Bureau's Activities on the Implementation of the Public Procurement System in 2007 (2008), available online.

${ }^{27} I d$., at 19.
} 
The second issue related to public procurement involves the nexus between municipal-level regulation and the provision of public services by state owned enterprises. According to Figure 5, the highest value of government contracts derived from public enterprises (whose internal over-sight is less than ideal). ${ }^{28}$ Moreover, chapter IX of the Public Procurement Law defines the procedures for public utilities (of which, many are covered by municipal-level providers) - namely water, energy, transport, postal services and other utilities. Yet, the chapter provides almost as many exceptions and exemptions to the Public Procurement as it imposes positive obligations.

Figure 6: Exclusions under Public Procurement Law

\begin{tabular}{|l|l|}
\hline area of exclusion & exclusions \\
\hline general & $\begin{array}{l}\text { when less than } € 500 \text { (art. 11), utilities contract part of bigger contract, } \\
\text { then can be “lumped in” (art. 178). }\end{array}$ \\
\hline water & $\begin{array}{l}\text { exempt if water production needed for non drinking purposes (art. } \\
\text { 181), the production of water is for operator's own use. }\end{array}$ \\
\hline gas, heat, electricity & $\begin{array}{l}\text { gas production occurs incidentally or as intermediary for other } \\
\text { production (art. 183). Electricity also exempt based on own-use (art. } \\
\text { 184). }\end{array}$ \\
\hline bus & exempt if other bus providers are already present (art. 186), \\
\hline infrastructure & airports, ports and terminals exempted (art. 188). \\
\hline \multicolumn{1}{|c|}{ Source: Law on Public Procurement (2008). }
\end{tabular}

Finally, the present Law on Public Procurement makes self-enforcement (through appeals from losing bidders) rather difficult. The Law provides extremely detailed provisions for the operation of a State Appeals Commission with the mandate to hear allegations of procurement related improprieties (arts. 200-229). However, the Law makes little provision for the public release of winning bidder information and no provision for independent audit or oversight of the procurement system. Indeed, under the current system, any bidder or third-party alleging any infraction of the Procurement Law should have enough evidence to convince the State Appeals Commission beyond a reasonable doubt - or face the payment of all court fees and top-up fines of up to $€ 300$ (arts 228-229). Such procedures are likely to have a chilling effect on individuals with suspicions of improprieties which could serve as useful intelligence in the investigation of procurementrelated corruption offences.

The issue of anti-competitive behaviour between municipal-level service providers represents one of the most challenging aspects of municipal anti-corruption reform in Macedonia -- particularly given the country’s small size. Municipal markets for water, electricity, lighting, parking and other municipal-level services face (or may face with additional private sector development) a number of issues related to collusion between service providers and members of procurement committees -- as well as face issues related to corrupt collusion among service providers themselves. ${ }^{29}$ Suppose, hypothetically, that parking services providers in Tetovo had colluded to either "farm rents" (namely use their government contract to collect payments - part of which they returned to one or more

\footnotetext{
${ }^{28}$ For the problems related to audit and oversight of Macedonian public enterprises (and all state bodies), see World Bank, Macedonia - Country Financial Accountability Assessment (2004), available online.

${ }^{29}$ Naturally, the Law on the Protection of Competition establishes that "agreements concluded between undertakings, decisions by associations of undertakings and concerted practice which have the prevention, restriction or distortion of competition as their objective or effect shall be prohibited" (as per article 7) except for block agreements (as defined in article 8 and contracts of minor importance as defined in article 9).
} 
members of the procurement commission). Such rents could also be used to pay off traffic police or regulations who oversee these parking service providers.

Municipal-level anti-corruption ordinance-making can address the issue of corrupt collusion in a number of ways. Figure 7a illustrates one possible solution to the simple hypothetical example (given previously) of collusion in parking service provision in Tetovo. The ordinance could encourage the procurement commission to split the contract - such that individuals parking their cars could choose where to park based on parking service provision by different parking lot operators. Alternatively, the contract could award parking service providers with the right to offer services anywhere in the municipality - encouraging competition among the two service providers. While the design of such a procurement seems counter-intuitive (and inefficient at first glance due to the additional complexity and cost of dealing with two service providers who perform the same service), the result would be to decrease the likelihood of collusion among parking service providers as well as between parking service providers and the procurement commission in Tetovo.

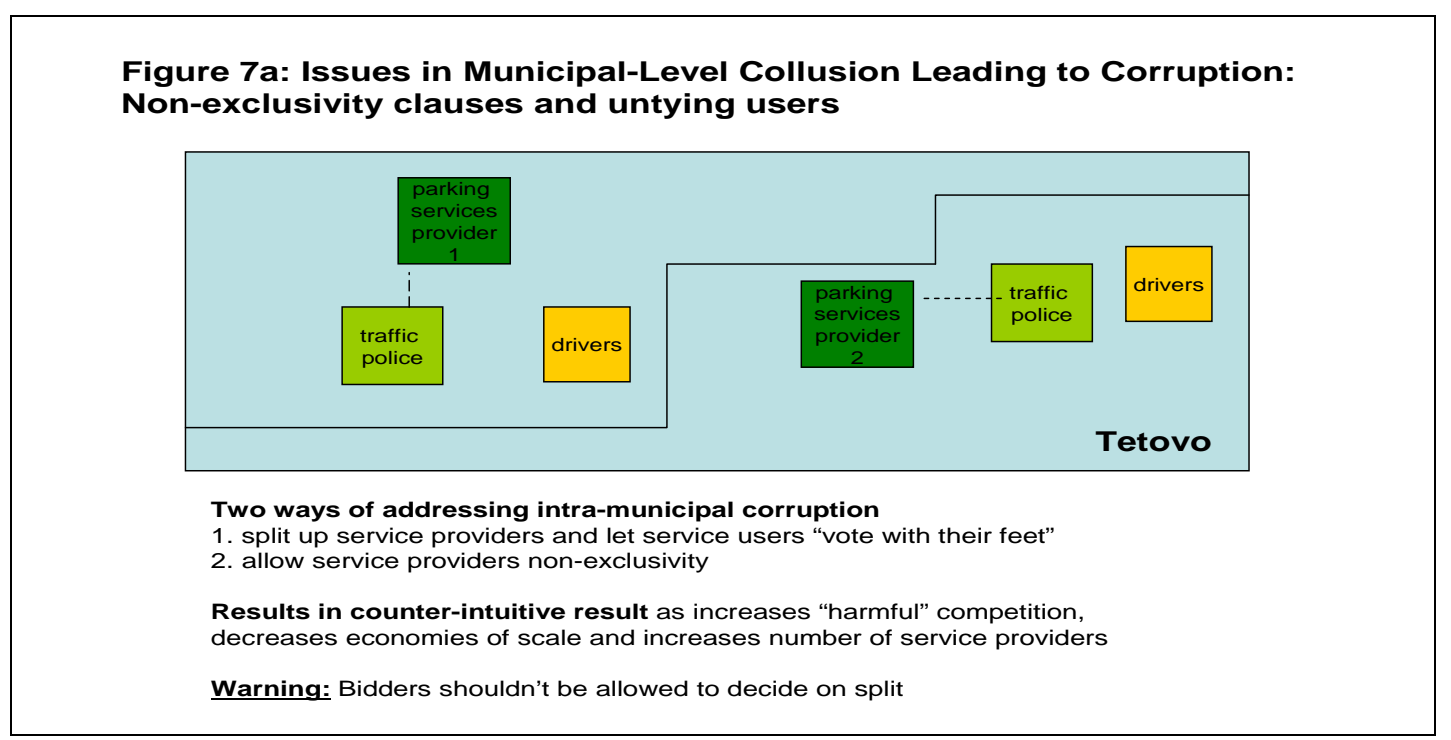

Corrupt collusion in municipal-level service provision may also result from the innocent repeated interaction with the same service provider - resulting in the forbearance of other service providers from entering the local market. Even if the chosen service provider represents the best value for money, the ensuing lack of an alternative provider may result in incentives for corruption (as shown in Figure 7b). Again, as the Law on Public Procurement remains silent on handling such cases, ordinance-based remedies may include encouraging - possibly contrary to the provisions of article 9 of the Public Procurement Law -- the procurement committee to split up contracts and encourage them to seek bidders from more distant locations. ${ }^{30}$

\footnotetext{
${ }^{30}$ Article 9 of the Public Procurement Law states “(1) Public procurement may not be divided into portions nor its estimated value may be reduced for the purposes of avoiding certain procedure determined by this law, and (2) Detailed rules on the estimated value of the procurement shall be stipulated by the Minister of Finance.” Article 9 does not completely prohibit the splitting of contracts, only such splitting "for the purposes of avoiding certain procedure determined by this law.” Clearly, the purpose of reducing municipallevel corruption does not seek to frustrate the intention of the Public Procurement Law - and thus can be (until a ruling by the Constitutional Court resolves the issue definitively) considered legal.
} 
Figure 7b: Issues in Municipal-Level Collusion Leading to Corruption: Deterrence, Barriers to Entry and "Maintenance of Competition"

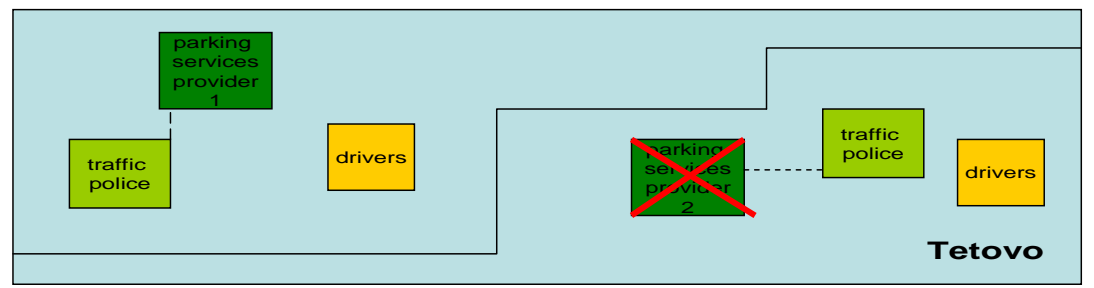

Repeated award of service delivery contract leads to elimination of competition 1. municipal service users have less or no freedom to choose

2. creates monopolistic market for service (and associated rents)

Results in counter-intuitive result to maintain second or third efficient service provider (even if market saturated). Weigh inefficiency costs against expected reduction in corruption.

Warning: Keeping "spare" service provider should be discretionary so as not to provide adverse incentives due to municipality commitments.

Corrupt collusion in the form of shrill-bidding also poses a serious problem which anti-corruption ordinance drafting could usefully target. The example in Figure 7c shows the case where corruption parking services company in Tetovo (bidding on a contract bringing in $€ 200,000$ in revenue) makes a corrupt transfer to another bidder in order to induce that bidder to submit a less appealing offer -- in exchange for $€ 20,000$. Again, encouraging the procurement commission to split the contract would reduce the incentives for the shrill (or collusive) bidder to seek and/or accept the corrupt side-payment. Fraud audits of both companies (or even the significant likelihood of such an audit) would also very likely reduce the incentives to engage in such side-payments. Local ordinances could impose such fraud audits (which are at present not required) and facilitate their implementation. ${ }^{31}$

\section{Figure 7c: Issues in Municipal-Level Collusion Leading to Corruption: Market sharing schemes and Shill Bidding}

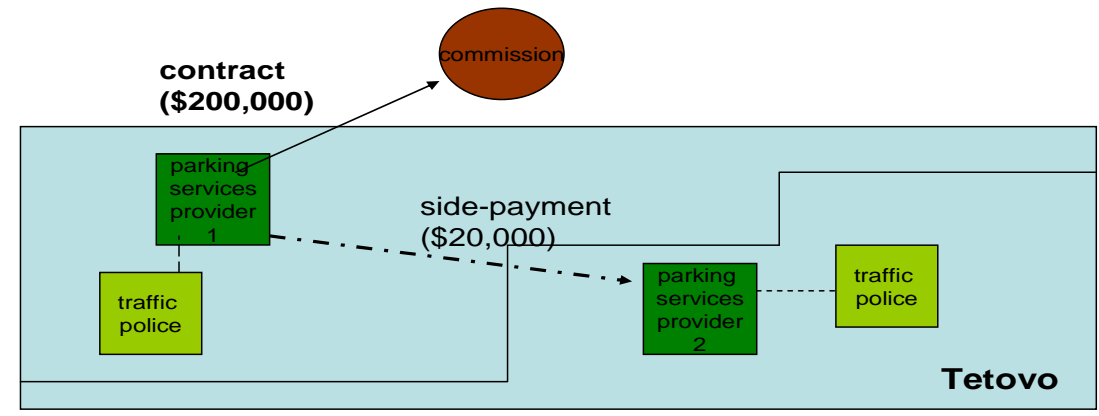

Two ways of addressing shrill bidding in intra-municipality tenders

1. allow municipality to choose more than one bidder and break up contract

2. unexplained wealth audits

Note: If full performance on contract, not necessarily worrying...

\footnotetext{
${ }^{31}$ See concur with Professor Williams who finds that suppliers convicted of corruption can not be excluded from future tenders (though they can of course be convicted of illegal commercial behaviour). See Sope Williams, The Use of Exclusions for Corruption in Developing Country Procurement: The Case of South Africa, J. AFRICAN L. (2007).
} 
Ordinance-based anti-corruption provisions may help address inter-municipal collusion-based corruption. Figure 7d demonstrates the case where a parking services provider from Kumanovo (continuing with the hypothetical case) bids on a tender in which the procurement commission and the parking services provider in Tetovo have colluded to prevent a competitive bidding process in Tetovo. In this example, an ordinance to encourage municipalities without a suitable second bidder to seek a tender from a provider in another municipality may help to reduce the close corrupt relationship between the commission and the Tetovo-based service provider. The Kumanovo parking services provider may also have increased incentives to appeal a lost tender due to less fear about reprisals which other Tetovo-based service providers may experience.

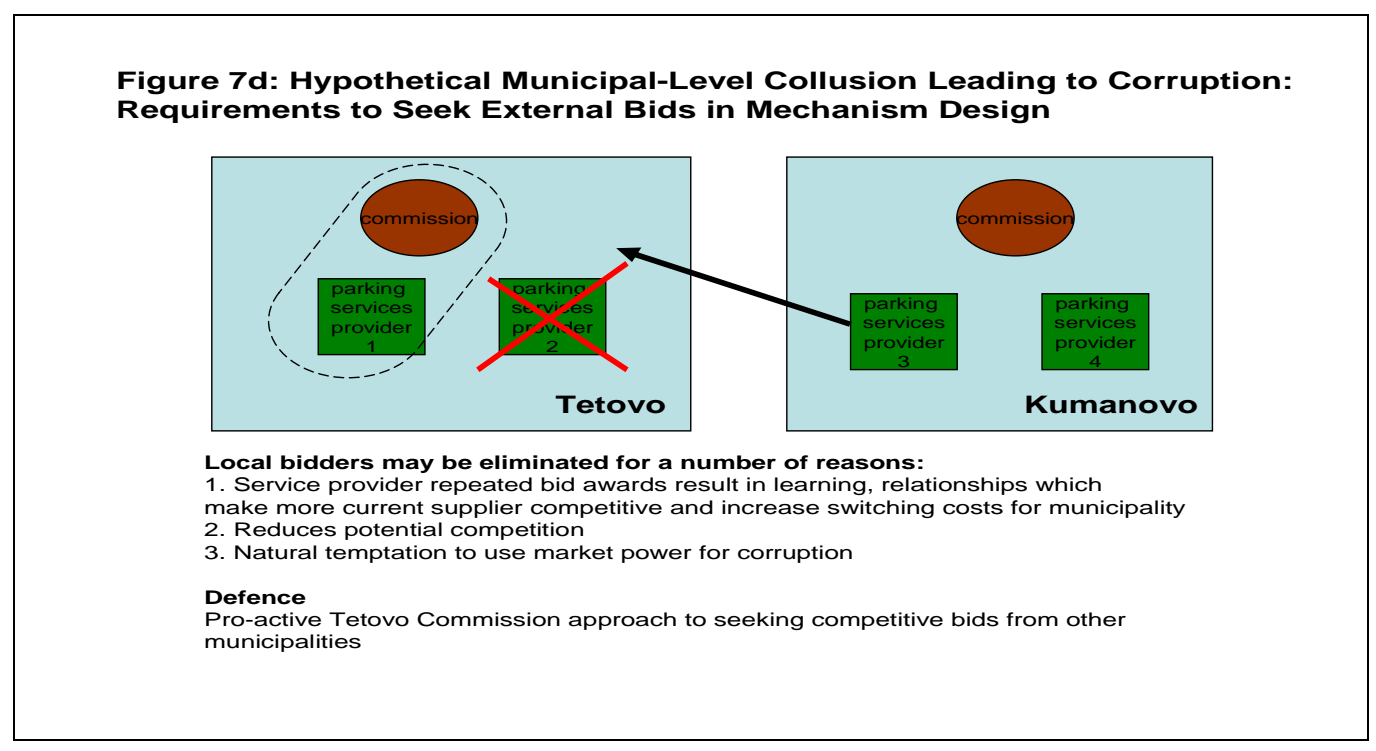

The handling of cases of inter-municipality collusion in the procurement process represents another lacuna in the existing legislation which could be tackled by anticorruption ordinances. Figure 7e illustrates the case in which a Kumanovo-based parking services provider colludes with a bidder in Tetovo in order to win a Kumanovo-based tender. The Kumanovo-based bidder based the most qualified Tetovo-based provider to "throw the bid" and receives the contract. Uncovering such collusion requires intermunicipal co-operation because the Kumanovo procurement commission's attempt to engage an external service provider could be seen as aimed at improving competition in the municipality. The other Tetovo firms would also have little or no incentive to denounce the corrupt service provider (indeed they could seek such future side payments themselves as well as benefit by the distraction of a rival). Alternatively, Kumanovo firm(s) could menace external service providers with physical or other harm if they enter "their" market. 
Figure 7e: Issues in Municipal-Level Collusion Leading to Corruption: Inter-municipal collusion, side-payments and barriers to entry

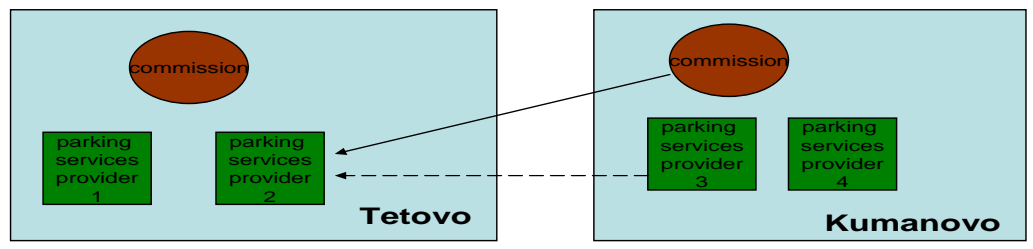

Kumanovo procurement commission does duty to seek outside bids 1. Kumanovo based provider gives side payment for Tetovo company to participate and "throw" the bid

2. Such a "side payment" could be negative (menace against participation)

3. Other Kumanovo firms free-ride from reduced competition from Tetovo

Not much can be done in this situation

1. Tetovo commissions don't have incentive to care

2. Tetovo competitors could seek (and thrive) such side payments instead

of providing public services

In the cases of inter-municipal corruption (as shown in Figure $7 \mathrm{f}$ ), the most effective legal (and administrative) remedy for corrupt collusion between bidders consists of ordinance-based co-ordination - instead of legislative-based solutions -- for two reasons. First, each municipality "pair" will have their own issues (area of public sector service more susceptible to corruption, monitoring mechanisms and so forth). Legislation can not provide the level of detail required of each municipality pair (or cluster). Second, municipal councils, rather than the Sobranie, are more likely to know which remedies would be most effective in their own municipality. ${ }^{32}$

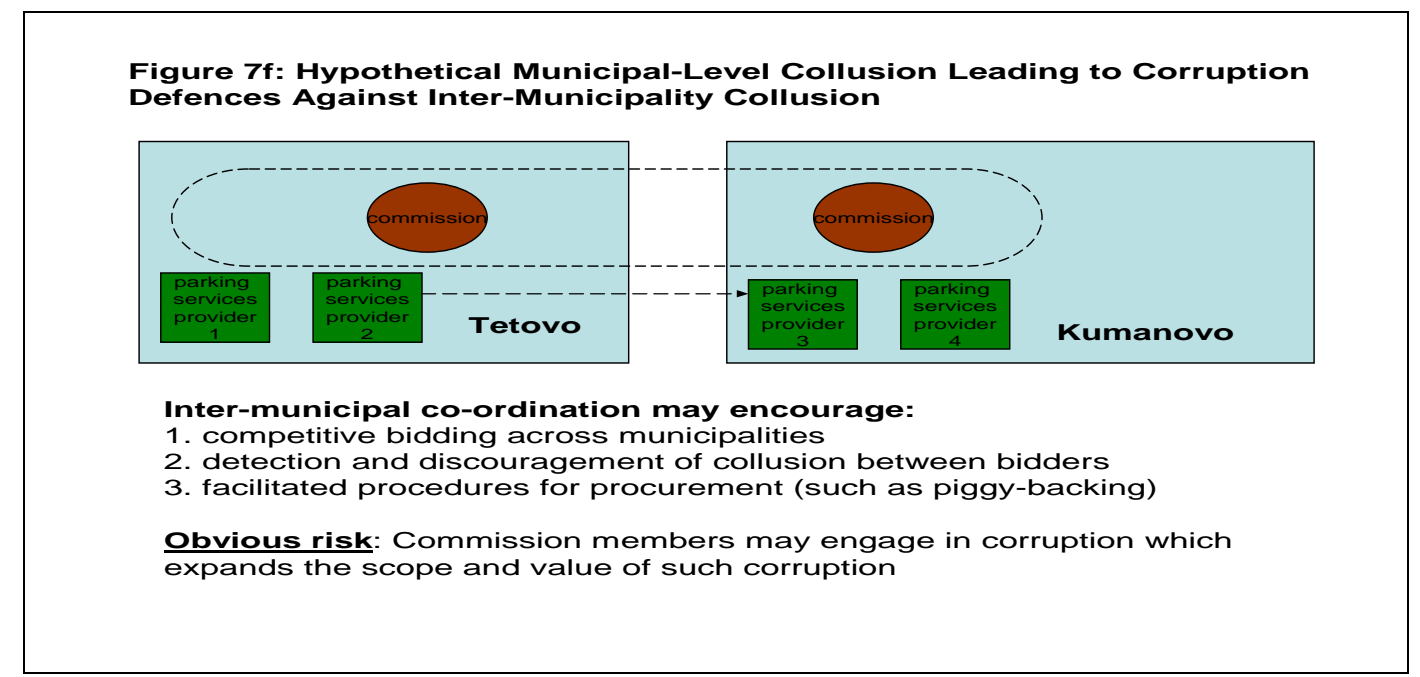

In order to guide procurement commissions, a municipal ordinance may define a three-part balancing test to determine when considerations about corruption risks should factor into a procurement commission's award of a tender. Clearly, a municipality should favour inter-municipal contracting in cases where the use of the more distant service provider reduces the likelihood of corruption in the municipality. However, in cases where a procurement commission member may seek alternative bidders, the person should ensure that he or she does run afoul of a perceived or actual conflict of interest. Finally, the procurement commission members, in deciding which bids to seek, should determine

\footnotetext{
${ }^{32}$ For an excellent overview of options for municipal co-operation in procurement, see N. Kovarik, Bang for Your Buck-An Analysis of How Efficient Public Procurement Laws Benefit Counties, Bidders, and Taxpayers, 39 GoNZ. L. REV. 575 (2003).
} 
whether the gain from cheaper goods outweighs imputed liability if municipality found corrupt? Each of these considerations are summarised in Figure 8.

\section{Figure 8: Balancing Test for Municipal Intervention in Procurement Based on Corruption Concerns}

1. Is the extra expense from using a more distant or more expensive goods/service provider outweighed by the potential loss from corruption?

2. Does the procurement lead to risk of prosecution under the Conflict of Interest Law?

3. Does the gain from cheaper or better goods and services outweigh the potential imputed liability to the municipality if the service provider is corrupt?

Municipal officials exercise discretion - possessing both the create local-level ordinances (at the political level) and exercise professional judgement in their work (at the executive/administrative level). Given the regulatory (and risk averse) nature of the state, municipal service regulations may proliferate - leading to economic incentives to pay bribes in order to avoid these voluminous regulations. Macedonia has adopted a comprehensive law on administrative fees which greatly reduces the ability to collect discretionary fees. ${ }^{33}$ Many countries use three other legal devices to help reduce the proliferation of red tape which helps generate corrupt rents (and thus rent-seeking behaviour): a Dillon-style Rule, a paperwork reduction act and/or regulatory oversight, and regulatory impact analysis. ${ }^{34}$ In Macedonia, ordinances with rent-seeking provisions can be quashed with difficulty, as no American-style oversight structure is in place to oversee ordinances. Relief from such ordinances relies upon certiorari motions by the State Commission. Against Corruption (hereinafter the State Commission) and appeals to administrative courts.

Individuals and organisations wishing to quash ordinances which provide incentives for municipal-level corruption may rely on two legislative articles. Article 57 of the Local Government Law allows the Constitutional Court to review ordinances for their "constitutionality and legality." While no constitutional issues may be present in ordinances which provide discretion or lead to corruption, the "legality" part of the article may invoke both the Anti-Corruption Law and the executive decision of the 11 November 2006 to implement Regulatory Impact Analysis (RIA). In practice, the judicial interpretation of "legality," will rely on Article 49 of the Law on the Prevention of Corruption which allows the State Commission to "give[] opinion[s] of proposed laws important for corruption prevention.” Clearly, according to its 2007 Annual Report, the State Commission has assumed such an oversight function over 19 laws in 2007. ${ }^{35}$ The Commission's work on regulations and particularly ordinances at the municipal level are unknown - particularly as municipalities are constitutionally guaranteed autonomy from

\footnotetext{
${ }^{33}$ Law on Administrative Fees. Available online.

${ }^{34}$ Each of these issues could form an entire treatise and thus we avoid describing and analysing them to save space for the legal analysis on Macedonian law which follows. The Dillon Rule refers to the US doctrine that cities have no inherent power except those which states devolve to them. The US passed in 1985 the Paperwork Reduction Act (44 U.S.C. 3501) which provides for the review of paperwork related requirements imposed on government service users. A number of offices in the US also ensure regulatory oversight over legislation (Office of the Management of the Budget) and various legislative affairs offices (which provide legal opinions on regulations and local level ordinances).

${ }^{35}$ State Commission for Prevention of Corruption, infra note 49 at 14.
} 
national authorities. ${ }^{36}$ Figure 9 provides a two part test for quashing rent-seeking ordinance provisions.

\section{Figure 9: Two part test for certiorari or injunctive relief from rent-seeking ordinances}

1. Does the ordinance provision pass (separately or as part of the overall ordinance) the Regulatory Impact Assessment?

2. Does State Commission review of the ordinance provision under its Article 49 (of the Anti-Corruption Law) lead to Commission to recommend striking or amending the provision?

Macedonia’s positive administrative silence legal provisions also may help reduce municipal corruption - but require additional clarification by municipal ordinance. Government Decree of the $28^{\text {th }}$ November 2006 establishes the legal basis for positive administrative silence in Macedonia (calling it the silence-is-consent provision). Relying on this Decree, economic operators receive the automatic right to engage in a regulated or restricted activity if the relevant public official does not respond to the petitioner's request for permission within a certain time. ${ }^{37}$ As government decree, rather than legislative fiat, has established positive administrative silence in Macedonia, an interesting legal question revolves around whether municipalities may bestow such a right upon municipal-level service users.

Municipal authority to extend the rights given by positive administrative silence to municipal service users relies on three conditions. First, and most obvious, the municipality (rather than a national entity) must possess the right or amenity - or be competent to issue an exception from an obligation -- which may be transferred by positive administrative silence. For example, the right to make a large hydro-electric plant on the Vardar River in the centre of Skopje may represent a right which the municipality does not have the right to give. Second, subsequent liability for the action must pass from the operator or person undertaking the action to the municipality. For example, if a large construction company builds a large shopping mall in the centre of Skopje (relying upon the municipal government's failure to respond to a building request), and a court subsequently finds the mall in violation of land development laws, the municipality should bear liability for damages to the company. Clearly, if the land developer must pay for the mall's removal, then no right had been transferred to the developer in the first place. Third, as positive administrative silence entails regulatory risk (some requests which should have been refused are allowed to proceed), positive administrative silence can only cover activities involving little social risk. Clearly, the right to store open-pit nuclear waste site confers a large social harm with only a marginal social gain. Figure 10 provides a three-part test for bestowing positive administrative silence rights in a municipal ordinance. $^{38}$

\footnotetext{
${ }^{36}$ Because (as will be shown later), the State Commission avails itself of few human and financial resources (and thus exercises a passive oversight role), the State Commission's effectiveness depends on whether victims of rent-seeking ordinance provisions make complaints. Such a factor militates heavily for the establishment of municipal-level anti-corruption agencies (as discussed later in this article).

${ }^{37}$ Decrees and other legal documents are difficult to obtain, particularly in English translation. For a reference to the Decree, see Cabinet of Deputy Prime Minister for Economic Affairs, Streamlining existing regulations and Strengthening Legislative Processes, available online.

${ }^{38}$ At first glance, the legal expert may be tempted to tie the rights conferred by positive administrative silence to the municipality's ability to respond to requests. Such a design, however, frustrates the intent of
} 


\section{Figure 10: Three part test for bestowing municipal-level rights under positive administrative silence}

1. Does the municipality have the legislatively defined right to bestow (or to restrict)?

2. Does the transfer of the right under positive administrative silence impute subsequent liability to the municipal government?

3. Would the cost of a failure result in a greater cost than all gains from the application of the rule?

An ordinance-based approach to clarifying positive administrative silence (particularly as a way to fighting corruption) seems less efficient than a legislative-based approach. An ordinance-based approach would ostensibly lead to different positive administrative silence rules for each of Macedonia's 84 municipalities. Different rules in different municipalities would probably increase the cost of uncertainty in inter-municipal business transactions. Yet, the Sobranie clearly does not have a view on the national treatment of positive administrative silence. Thus, while increasing the cost of business, regulatory competition (in this case competition between ordinances) could also produce socially-desirable learning; partially as particular municipalities find themselves giving rights under positive administrative silence in order to harmonise with other municipalities (resulting in the famous gains from policy diffusion). Should very diverging approaches to positive administrative silence remain enshrined in various ordinances across Macedonia, the confusion and conflict arising from the patchwork of ordinances would encourage (liberal and pro-active) legislation - as the parliament becomes obliged to pass legislation related to positive administrative silence. Ordinances are also more easily repealed than national legislation -- making municipal councils the preferred fora for deciding questions related to little understood policies (such as positive administrative silence).

Municipal-level service providers are often viewed as more accountable than their national-level line-ministry service provider peers. ${ }^{39}$ Local level politicians manage municipal services (with their authority derived from the electorate and delegated to professional managers of the public services under their charge). Objective municipal service performance indicators help both local politicians and managers manage public services - and particularly surveys which (as the handbook of municipal councillors and mayors notes), "may very much improve the position of municipal representatives, since most of their decisions should be approved and supported by the majority of the public." 40 The collection of data about municipal service delivery often consists of "scorecard"

the mechanism. One of the goals of positive administrative silence provisions aims to transfer liability to municipality authorities and to encourage them to make investments in dealing promptly with public service users.

${ }^{39}$ See Claudio Ferraz \& Frederico Finan, Electoral Accountability and Corruption in Local Governments: Evidence from Audit Reports, IZA DISCUSSION PAPER No. 2843 (2007) [who conduct an innovative study of municipal government audit reports from Brazil to show an empirical relationship between local political accountability (as proxied by local rules regarding mayoral re-election) and corruption (as proxied by resource misappropriation).

${ }^{40}$ Association of Local Self - Government Units (ZELS), Handbook for Mayors and Municipal Council Members of the Republic of Macedonia, at 124, available online, [provides a useful vade mecum for municipal policy in the Republic]. 
surveys. ${ }^{41}$ Such scorecard surveys ask municipal service users about their objective and subjective experiences with the local parks service, electricity provision and other activities within municipal jurisdiction. ${ }^{42}$

While most analysts agree that such surveys or scorecards provide a useful municipal-level tool in the fight against corruption, legal scholars have not contributed to the debate - particularly as to whether such service delivery surveys should be legally obligatory. First, the State Audit Law clearly establishes the legal basis of such surveys (and reiterates the government's commitment to using any method which promotes the “economy...efficiency...[and] effectiveness] of state expenditures". ${ }^{43}$ Second, Macedonian jurisprudence in general appears to favour such activities. Besides, the provisions laid down in the Public Procurement Law, State Audit Law, the Law on Civil Servants and the various Laws governing various state bodies - such as the Customs Implementing Law the Law on Public Administration requires that "administrative bodies, shall implement the stipulated policy of the Government and of the [Parliament]...monitoring the situations in the area they are established for, giving initiative for solving the issues, dealing with administrative affairs, performing administrative surve[ies] and other administrative matters." 44 The law, thus, establishes a clear right to conduct such surveys or scorecards and suggests the imposition of a legal obligation. Clearly, any municipal council which loses money or provides sub-adequate services because the council failed to seek data related to service delivery problems would be found negligent (politically and even possibly guilty of committing a delict against its citizens). Macedonian municipalities can clearly be found to act (or fail to act) in the interests of its trustees (citizens) - imposing a legal obligation to conduct surveys if such surveys help thwart harms stemming from inefficient or corrupt administration. ${ }^{45}$

Because the legal obligation to conduct service delivery surveys relies on legal interpretation, the subsidiary question about the level at which such an obligation is (or should be) established remains even less clearly defined in Macedonian law. Namely, should service delivery surveys be legally required at the legislative, regulatory or ordinance level? In this respect, as most public service provision at the municipal level occurs through public enterprises, the Law on Public Enterprises provides little clarity about whether surveys may be required of these enterprises. ${ }^{46}$ On the one hand, these enterprises are required to submit development plans - and thus the results of any survey would only have an impact on the following year's development plans (if at all). On the other hand, the municipality issues the licence for the public enterprise and can easily enough insist on the conduct service delivery surveys as part of the enterprise's licensing

\footnotetext{
${ }^{41}$ See G. Thampi \& S Sekhar, Citizen Report Cards, in CHARLES J. G. SAMPFORD, ARTHUR SHACKLOCK, CARMel Connors, Fredrik Galtung, MEAsuring Corruption (2006).

${ }^{42}$ Municipalities, like all public sector entities, have been involved in e-government initiatives aimed at providing the public information as a way of fighting corruption. See the Skopje Accountability Through Transparency Initiative online.

${ }^{43}$ State Audit Law, article 3.

${ }^{44}$ Law on Public Administration, at art. 69.

${ }^{45}$ While affording Macedonian companies some protection from liability in cases of public service failures (and helping to prevent such failures before they occur, the legal imposition of a requirement to conduct service delivery surveys acts as tax on Macedonian enterprise. In public economics theory, a $\mathrm{n} \%$ increase in the cost of business results in a n-squared distortion to the economy. As such, market-distorting requirements (such as the legal obligation to conduct surveys) should be used sparingly.

${ }^{46}$ The activities outlined in article 2 of the Law on Public Enterprises which correspond with the article 17 activities defined in the Local Government Law include activities related to the energy sector, public transport, telecommunications, utilisation of forests, waters, pastures and other types of natural resources, physical planning, public utilities, veterinary and sports.
} 
requirements. ${ }^{47}$ Figure 11 summarises the issues involved in legislative-based service delivery survey mandates, as well as alternative mandates which may favour ordinancebased approaches.

The range of anti-corruption issues which municipalities must grapple with suggests the need for municipal-level anti-corruption agencies. As the issues suggest, the municipal councils can not tackle the wide range of issues related to the oversight of public procurement, the review of ordinance provisions, and the conduct of service delivery surveys alone. Nor can they rely on national level institutions such as the State Commission, given the lack of resources and man-power. An organisational structure should be put in place which involves the participation of municipalities, while engaging the national institutions competent to fight corruption in Macedonia.

\footnotetext{
${ }^{47}$ Article 43 of the Law on Public Enterprises requires any public enterprise to obtain a licence (following the procedures defined in subsequent articles of the law).
} 


\section{Figure 11: Should Service Delivery Surveys be Covered by Anti-Corruption Ordinance-Making?}

Service Delivery Surveys in Macedonia are little conducted for both central services and municipal services. The following represents four views about the imposition of legislative obligations with regard to the conduct of surveys.

Laissez-fair approach - Such an approach argues for the voluntary nature of the conduct of such surveys. Both municipalities and service providers assume risk for failing to ensure that service levels are acceptable - but they assume such a risk as part of their overall costbenefit calculations. One argument for such an approach stems from empirical work showing that surveys and measurements are more effective when developed internally rather than externally. ${ }^{48}$ Another argument notes that the local political process, rather than bureaucratic surveys, should provide for local-government accountability. ${ }^{49}$

Service provider (enterprise) level - the (mostly public) enterprises which provide municipal-regulated services should establish the requirements for their own service delivery surveys as part of their marketing department functions. Such a requirement may be embodied in their organic statute (articles of association) or instruction from the management board or general manager. ${ }^{50}$ The larger firms will have experience with surveys and the company's internal auditor can use these data to flag service delivery problems before the municipal authorities need to become involved.

Municipal-level obligation - as previously noted, municipalities clearly have the legal authority to require service delivery surveys by public enterprises under their jurisdiction. Ordinance-based survey provisions may be required in order to ensure an "equal playing field" (namely that all service providers face the same costs). A municipal obligation may also provide uniformity across survey indicators - so different services may be compared.

Legislative requirement - the Sobranie clearly has the legal right to legislate on municipal matters. The case for legislating on such a minor issue revolves around the constitutional issue of equality - namely ensuring fair access to public services for all citizens (as municipalities with service delivery surveys may provide better services to their citizens than others). Legislation can also ensure a certain quality of survey (such that the survey methodology follows accepted social science practice) and some survey items are comparable in order to allow for benchmarking (used to identify best-in-class and underperforming managers).

Source: authors.

\footnotetext{
${ }^{48}$ Simon James, Kristina Murphy \& Monika Reinhart, The Citizen’. Charter: How Such Initiatives Might Be More Effective, 20 PUB. POL'Y \& ADMIN 2, 1-18 (2005) [the authors show how citizens charters in the UK were effective only with voluntary surveys. When authorities (such as the tax police) initiated these initiatives, they met with much more success than if survey work was imposed by legal fiat.

${ }^{49}$ As in most countries, the collection of public service users' opinions of public service delivery has remained unlegislated on the grounds that accountability for such service provision resulted from the local political process (namely mayors and municipal councils who failed to delivered adequate public services would be voted out of office).

${ }^{50}$ See Law on Public Enterprises, at article 11 (for incorporating documents) and article 16 (for management composition).
} 


\section{The Reasons for and Structure of Anti-Corruption Agencies for Municipal Authorities}

The Macedonia central government - and particularly the State Commission for the Prevention of Corruption (the State Commission) - does not have the resources to effectively tackle the large volume of corrupt transactions in the country. Figure 12 shows the cases handled by the State Commission in 2007. ${ }^{51}$ Supervising a total of roughly 17,000 civil servants, the State Commission opened a little less than 600 cases in 2007 (representing complaints against 3.5\% of all civil servants) with a budget of €312,000 (or $€ 283$ for each of its 1,100 pending cases - representing less than one day's wages for an average Western EU investigator). ${ }^{52}$ Reflecting Macedonia's passive system of anticorruption law enforcement (relying on complaints instead of pro-actively initiating audits or probes which may lead to the uncovering of wrong-doings), only 12 cases resulted from the State Commission's own initiative - corresponding to roughly one case per Commission civil servant. ${ }^{53}$

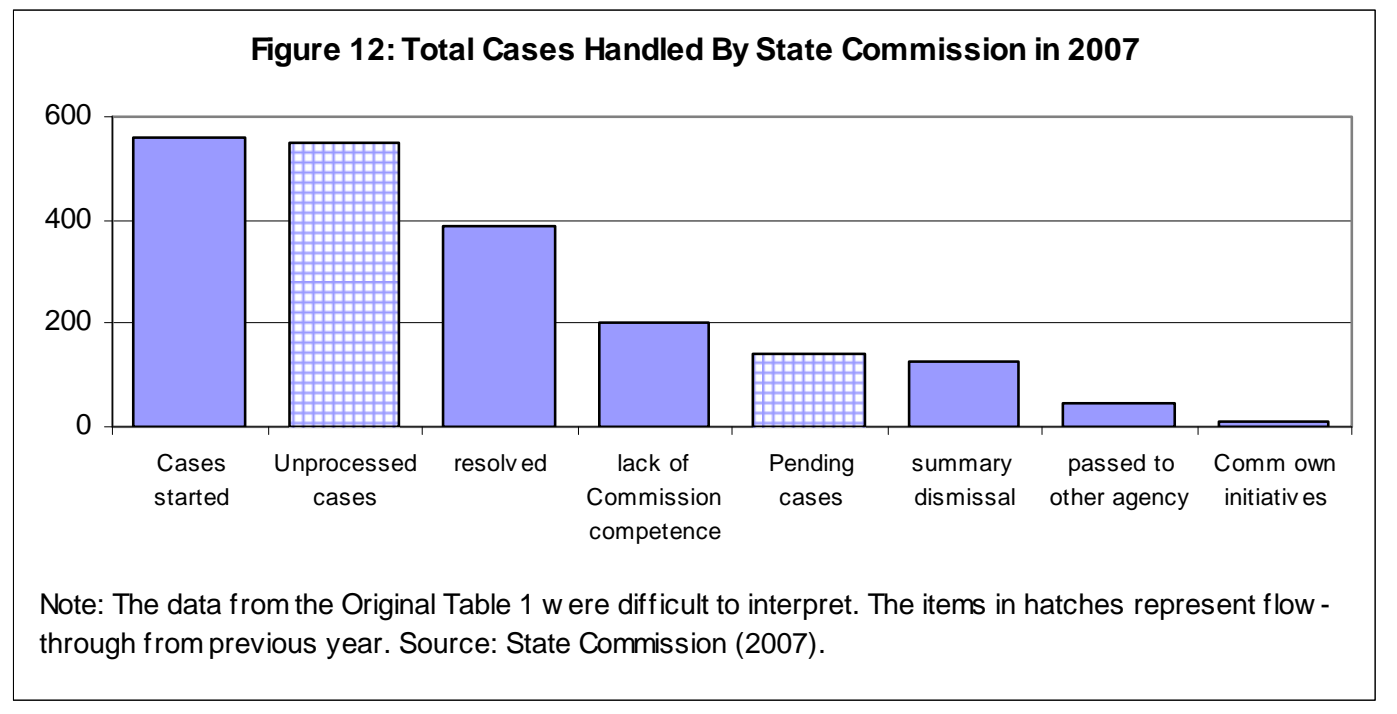

Of the cases handled by the State Commission, a large number consist of cases related to central or municipal authorities - and few are handled successfully. Figure 13 shows complaints specifically about Macedonian national and municipal government officials (as opposed to overall complaints which include corruption in privatisation proceedings, health and educational establishments, public sector enterprises and other institutions). Of the roughly 350 complaints received, only 3 resulted in significant action by the State Commission (1 involved a criminal indictment, 1 resulted in a recommendation and 1 complaint led to a misdemeanor charge being filed against the accused). The State Commission's Annual Report does not provide statistics specifically about municipalities, other than the number of letters sent to municipal bodies about complaints versus the number of responses the State Commission received. Of the 52 letters send to municipalities (out of a total of 215 letters or roughly $25 \%$ of all letters), the State Commission received 28 out of 130 total responses or roughly 20\% of responses coming from municipalities).

\footnotetext{
${ }^{51}$ These graphs are taken from State Commission for Prevention of Corruption, Annual Report in 2007. (2008). Available online at 53.

${ }^{52}$ Id., at 10.

${ }^{53}$ Id., at 11 [In 2007, the State Commission had a staff of 11 civil servants].
} 


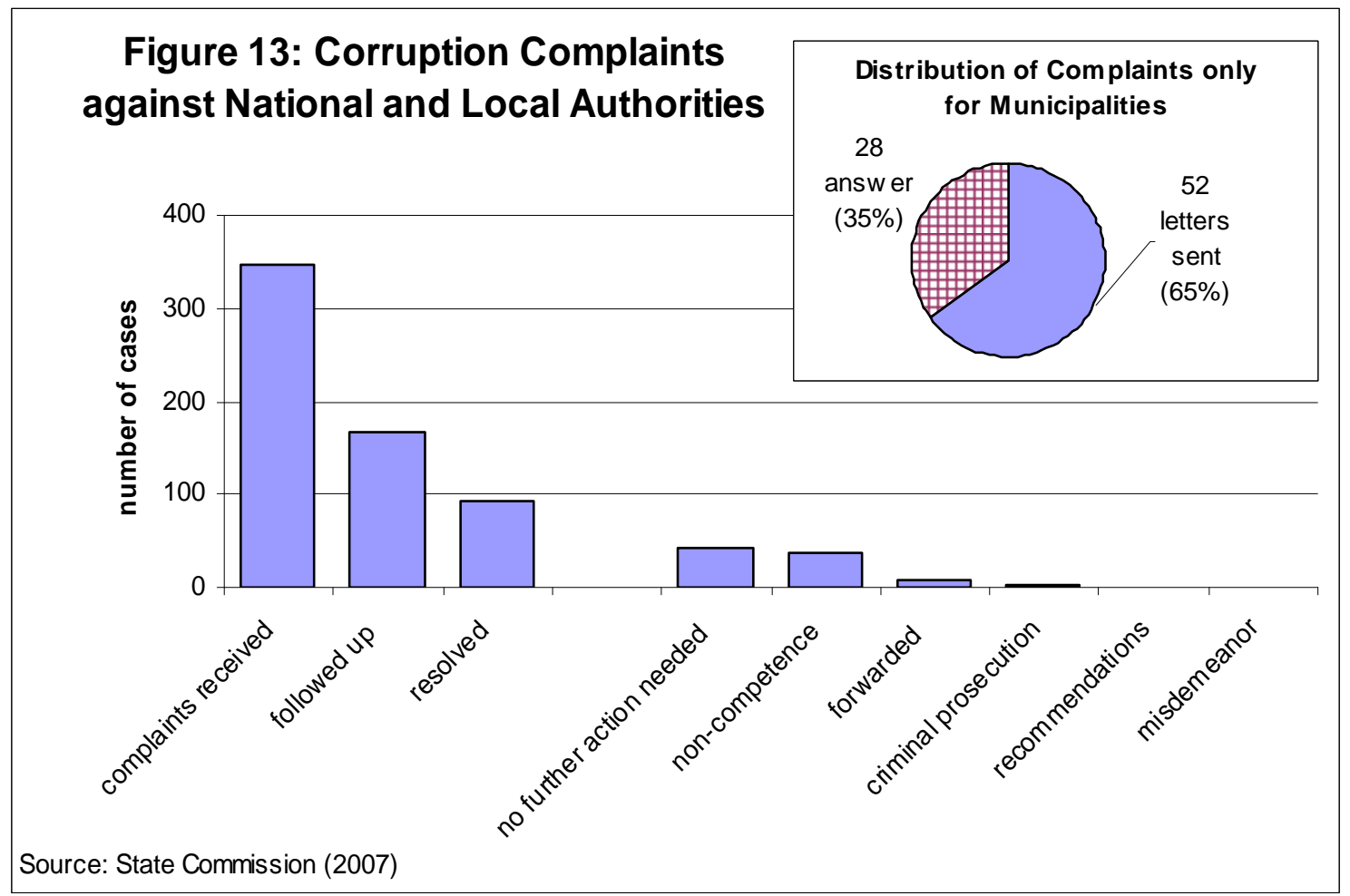

These limited data from the State Commission about follow-up on corruption allegations involving municipal government or service providers leads to two conclusions. First, the State Commission does not have the resources needed to effectively tackle municipal-level corruption. Second, the State Commission does not receive the level of co-operation from municipalities required in order to address municipal level corruption. The sanctions envisioned in the Anti-Corruption Law may provide part of the explanation for municipal-level lack of co-operation. Such sanctions are not likely to be "effective, proportionate and dissuasive” as required by article 26(4) of the UN Convention Against Corruption. According to articles 61-66 of the Anti-Corruption Law, the fine for noncriminal corruption offences ranges from $€ 333$ to $€ 833$. Clearly, the State Commission requires assistance from other state bodies if the Commission hopes to effectively tackle corruption.

Municipal-level anti-corruption agencies are required in order to effectively tackle Macedonian municipal-level corruption. Professor Meagher defines an anti-corruption agency as a "separate, permanent [entity] whose primary function is to provide centralized leadership in core areas of anti-corruption activity. The latter include policy analysis and technical assistance in prevention, public outreach and information, monitoring, investigation, and prosecution." 54 While Professor Meagher intended the "centralised leadership" to refer to centralisation at the national (or federal) level, such centralisation can also refer to the municipal level. In various countries, such "agencies" consist of independent offices, but also may be commissions, committees, or even inter-departmental agencies - thus municipal-level agencies may take a possible number of organisational forms.

\footnotetext{
${ }^{54}$ Patrick Meagher, The Anti-corruption Agencies: Rhetoric versus Reality, 8 J. PoL. RefORM 1, 69, 103 (2005) at 70 [I have replaced the word "agencies" with "entity" to prevent the definition from being tautological].
} 
Macedonian municipal councils clearly have the mandate to establish such anticorruption agencies. Article 19 of the Local Government Law provides that municipal governments may be mandated (by central government agencies) with the responsibilities of central government if they are able to perform these responsibilities more effectively. ${ }^{55}$ Article 17 of the same law further establishes that municipal governments (and their dependencies) may:

a) "adopt development programs which are of importance to the unit of local selfgovernment and citizens on issues under its jurisdiction (ss 1);

b) "establish public services, public institutions and public enterprises for the performance of matters of local relevance....and exert control over their operations (ss 29),

c) establish inspection agencies and services in areas for which the units of local selfgovernment have original jurisdiction in the regulation and performance of issues from those areas (ss 30) and

d) determine offences and penalties when the ordinances of the unit of local selfgovernment are violated (ss 31). ${ }^{56}$

The State Commission from its side should (in theory) have the authority to devolve part of its competencies to such municipal-level anti-corruption agencies. Chapter $\mathrm{V}$ of the Anti-Corruption Law does not explicitly grant or deny the State Commission the authority to delegate part of its functions to other government agencies. The only provision which the State Commission (and the state agency receiving the delegated mandate) may rely upon in cases where the State Commission agrees to the devolution of its responsibilities falls under article 49 of the Anti-Corruption Law (which delineates the jurisdiction of the State Commission). In the article, the State Commission may "cooperate[] with other state bodies in the suppression of corruption." Clearly, the term "co-operate" may (or may not) provide the State Commission with the authority to devolve some of the other competencies granted to it (and required of it) in article 49.

The devolution of State Commission's competencies -- based on the meaning of the term "co-operate" -- hinges on two elements. The first element relies upon the State Commission and each municipality's (or more likely the Association of Units of Local Self-Government or ZELS's) ability to enter into a Memorandum of Understanding or Protocol - establishing a principal-agent relationship between the State Commission and the municipalities. ${ }^{57}$ As the State Commission has already entered into a number of such

\footnotetext{
${ }^{55}$ Article 19 establishes that "The Republic may, by this and other laws, entrust to the units of local selfgovernment the responsibly to perform certain activities under jurisdiction of the organs of State administration

for a more efficient and rational exercise of the rights and duties of its citizens and for the satisfaction of certain needs of direct interests of the citizens." Sub-point (3) of the same article requires these central agencies to allocate funding for any mandates they may bestow upon municipal government.

${ }^{56}$ Article 29 empowers the municipal councils to oversee the implementation of each of these points in points 9, 10 and 11 respectively. Clearly, an anti-corruption agency would qualify under each of the four sub-points cited for Article 17 in defence of the municipality’s right to establish municipal-level anticorruption agencies.

${ }^{57}$ The ZELS does not have the authority to enter into agreements on behalf of its members and could only serve as honest broker, see supra note 88 for the ZELS's competencies.
} 
agreements, clearly the first element succeeds. ${ }^{58}$ The second element relies upon a Macedonian administrative court vacating any appeals made of corruption related decisions (or the work of such municipal-level anti-corruption agencies) on the grounds that the municipal authority had acted ultra vires. ${ }^{59}$ Figure 14 summarises these considerations in the form a legal test for the legality of municipal-level anti-corruption agencies in Macedonia whose competencies derive from the devolved responsibilities of the State Commission.

\section{Figure 14: Three Part Test for the Validity of the Establishment of Municipal Level Anti-Corruption Agencies in Macedonia}

1. Does Article 17 of the Local Government Law empower municipalities to singly or jointly establish an anti-corruption agency with delegated authority from the State Commission based on of their "importance to the unit of local self-government and citizens"

2. Can the term "co-operate" in Article 49 of the Anti-Corruption Law be defined loosely enough to establish a principal-agent relationship between the State Commission and municipal authorities?

3. Will an appeal of a municipal-level anti-corruption agency decision fail on the grounds that the agency did not act ultra vires?

The competencies of the municipal-level anti-corruption agencies rely (naturally) on the competencies available to the State Commission to devolve, as well as on the competencies which municipalities possess as part of their own authority to self-govern. Figure 15 provides an overview of each of these competencies - along with the ways which the State Commission could exercise a regulatory role over potential municipal level anti-corruption agencies (in order that these agencies assume the majority of the labour intensive work from State Commission officials).

Public education comprises an important anti-corruption policy issue for which the State Commission has not been able to fulfil its legislatively imposed obligations. Of the major anti-corruption public awareness campaigns in Macedonia, the main campaigns have been conducted by the Macedonian Customs Administration (though the posting of "no bribery" posters and the establishment of its toll-free 197 complaints hotline) as well as Transparency International - Macedonia's poster campaigns and the offer of legal advice. Indeed, the State Commission relies on Transparency International - Macedonia to work with the public on legal counselling and has little interaction with the public. Municipal-level anti-corruption agencies would help the State Commission address that extremely important class of citizens, potential victims of bribery and actual (willing or unwilling) accomplices in bribery offences. ${ }^{60}$

\footnotetext{
${ }^{58}$ An example of such an agreement comprises the Christmas Day Protocol between the State Commission and the Public Revenue Office, Public Prosecution Office, Public Procurator Office, Judicial Council, Ministry of Interior, State Audit Office, Customs Administration, Directorate for Financial Police, Directorate for the Prevention of Money Laundering and the State Authority for Geodetic Works in 2007.

${ }^{59}$ Clearly, any decision finding that the municipal anti-corruption agency acted beyond the scope of its powers would be tantamount to striking down the validity of any scheme of "co-operation” between the State Commission and municipal anti-corruption agencies.

${ }^{60}$ For authors such as Professor Carr, such an educational function would represent the most important part of the State Commission's work. Professor Carr represents one of the strongest critics of legal action against
} 
Figure 15: Competencies of Municipal-Level Anti-Corruption Agencies

\begin{tabular}{|c|c|c|}
\hline Article 49 Competence & $\begin{array}{l}\text { State Commission's Regulatory } \\
\text { Function }\end{array}$ & $\begin{array}{l}\text { Municipalities' Devolved } \\
\text { Competence }\end{array}$ \\
\hline gives opinions about laws & $\begin{array}{l}\text { - provide guidance to municipality- } \\
\text { level anti-corruption agencies about } \\
\text { ruling on ordinances } \\
\text { - receives municipalities’ legal } \\
\text { opinions on ordinances }\end{array}$ & $\begin{array}{l}\text { - provides rulings on ordinances if } \\
\text { impact on corruption } \\
\text { - refers contentious cases to State } \\
\text { Commission }\end{array}$ \\
\hline $\begin{array}{l}\text { proposals for supervising } \\
\text { political parties }\end{array}$ & $\begin{array}{l}\text { - provide guidance and if necessary } \\
\text { pass views to Electoral Commission }\end{array}$ & $\begin{array}{l}\text { - supervise local elections and } \\
\text { receive complaints }\end{array}$ \\
\hline $\begin{array}{l}\text { proposals for supervising } \\
\text { NGOs }\end{array}$ & $\begin{array}{l}\text { - regular oversight and learning from } \\
\text { municipal ant-corruption agency "best } \\
\text { practice” }\end{array}$ & $\begin{array}{l}\text { - act as first screener for proposals } \\
\text { related to regulating NGOs for } \\
\text { corruption }\end{array}$ \\
\hline $\begin{array}{l}\text { considers conflict of interest } \\
\text { cases }\end{array}$ & $\begin{array}{l}\text { - provides guidelines for auditing } \\
\text { interest declarations }\end{array}$ & \\
\hline $\begin{array}{l}\text { follows changes in wealth of } \\
\text { local officials }\end{array}$ & $\begin{array}{l}\text { - provides instructions on conducting } \\
\text { random audits } \\
\text { - allows for “community policing” }\end{array}$ & $\begin{array}{l}\text { - conducts random audits (driving } \\
\text { past officials house to see if } \\
\text { corresponds to declared interest, } \\
\text { etc). }\end{array}$ \\
\hline $\begin{array}{l}\text { co-operates with other state } \\
\text { agencies }\end{array}$ & $\begin{array}{l}\text { - serves as voice for municipal level } \\
\text { anti-corruption agencies vis-a-vis state } \\
\text { agencies } \\
\text { - negotiates ability to receive } \\
\text { complaints about state administration } \\
\text { (health and education in particular) }\end{array}$ & $\begin{array}{l}\text { - focuses on high risk sectors of } \\
\text { health and education (if allowed) } \\
\text { - receives local complaints about } \\
\text { teachers, doctors and other local } \\
\text { level service providers }\end{array}$ \\
\hline provides education & $\begin{array}{l}\text { - learning from municipal ant- } \\
\text { corruption agency "best practice” }\end{array}$ & $\begin{array}{l}\text { - works with local NGOs and law } \\
\text { enforcement officials on behalf of } \\
\text { State Commission }\end{array}$ \\
\hline \multicolumn{3}{|c|}{ Competencies under Local Government Law } \\
\hline Article 29(10) & Probably negotiated through ZELS* & $\begin{array}{l}\text { - handling of non-criminal } \\
\text { disciplinary proceedings }\end{array}$ \\
\hline Article 29(9) & Probably negotiated through ZELS & $\begin{array}{l}\text { - corruption risk audit } \\
\text { - risk profiles of staff }\end{array}$ \\
\hline
\end{tabular}

Source: authors.

* ZELS refers to the Association of the Units of Local Self-Government (see next section for more).

As Macedonia clearly should not have 84 municipal-level anti-corruption agencies, only a limited number of municipal-level agencies should be established. The Local Government Law provides that "the units of local self-government shall cooperate among themselves" and may "in order to achieve their common interests and to perform common tasks with the framework of their jurisdiction in a broader territory, the units of local selfgovernment may join funds and establish common services, organizations, public enterprises and public services." 61 As such, the Law clearly provides the basis for municipal-level anti-corruption agencies with inter-municipality jurisdiction (namely established as the co-operative effort of several municipalities).

The "optimal location" of these agencies should balance the costs and benefits of agglomerating municipalities. The social and budgetary costs of establishing these agencies depend on the cost of staffing, providing offices, training, and the time and effort of individuals who make corruption-related complaints. The benefits of such municipallevel anti-corruption agencies stem from the increased number of complaints which the

\footnotetext{
${ }^{61}$ Law on Local Self-Government, at article 10.
} 
State Commission could indirectly process, the increased tax and customs revenue deriving from successfully prosecuted complaints and investigations - and ultimately increased revenue to Macedonian and foreign business (who are spared the transactions costs involved with bribery). Figure 16 shows the results of a "gravity" model which has been used in some of the applied economic work to decide on the optimal location of a service provider - in this case the anti-corruption agency. ${ }^{62}$

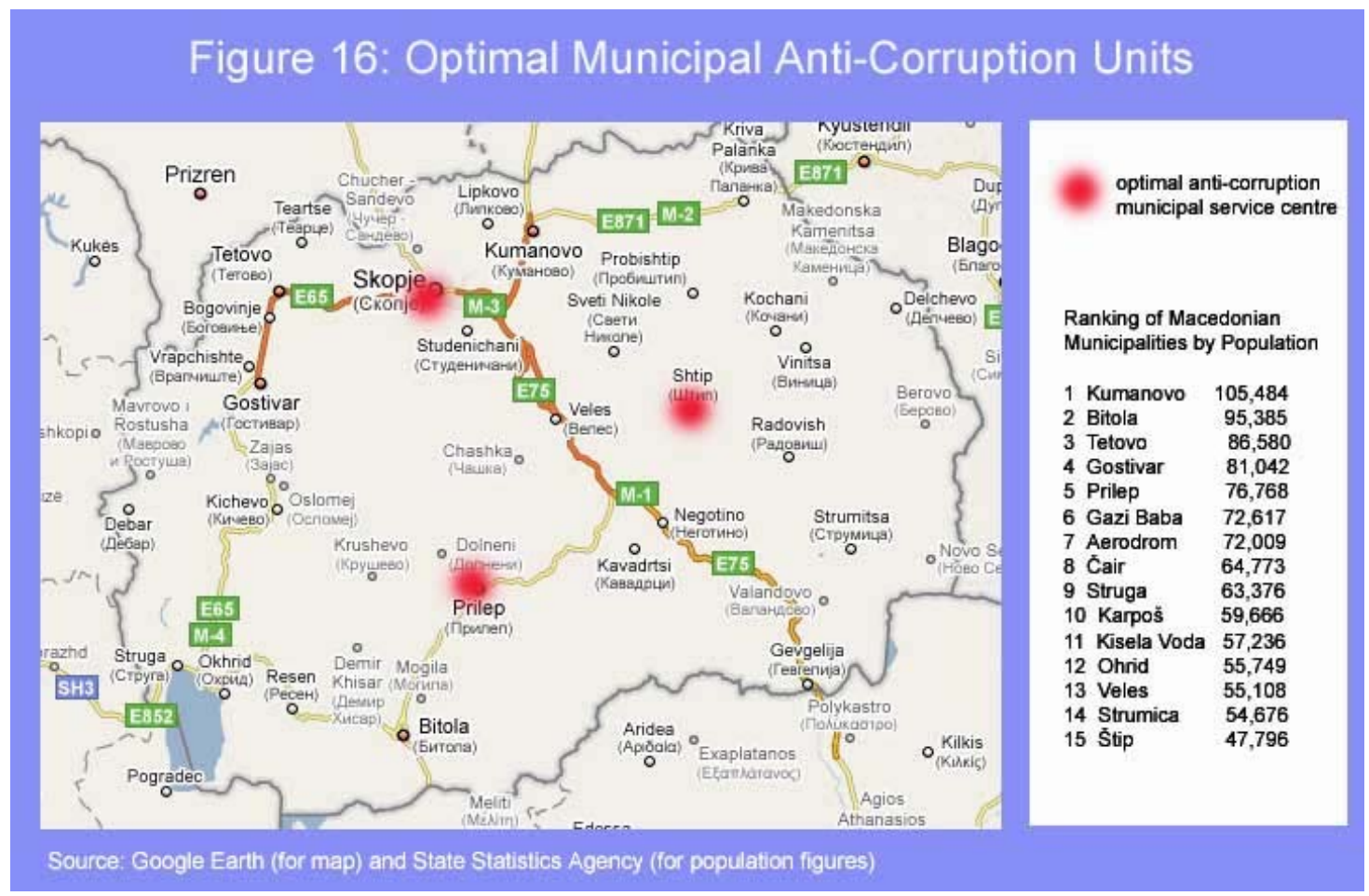

The largest benefit of such municipal-level anti-corruption agencies (with the delegated authority from the State Commission) derives from their ability to watch over municipal government interests. These agencies also benefit from flexible and responsive law-making (by municipal councils) which becomes difficult at the national (legislative) level. ${ }^{63}$ In particular, the relevant Macedonian legislation which could empower law enforcement agencies to offer rewards to witnesses or other third-parties for helping to solve crimes (such as corruption) remains conspicuously absent. However, the payment of such rewards (or qui tam rewards as will be discussed in the next section) can be done by these municipal-level anti-corruption agencies without requiring national legislation particularly as a discretionary reward rather than automatic entitlement.

\section{Implementing Qui Tam at the Municipal Level}

Qui tam actions (or law suits) allows individuals who denounce corruption (or any other offence against the financial interests of the state) to obtain a share of the damages

\footnotetext{
${ }^{62}$ See Bryane Michael, Explaining Organizational Change in International Development: The Role of Complexity in Anti-Corruption Work, 16 J. INTL DEV. 8, 1067 - 1088 [which provides in more detail the gravity model referred to in the text].

63 The other "location" issue consists of the organisational form by which the municipal-level anti-corruption agency chooses. Some possible options include -- as a special office established by the municipal council, as an extra office to an already established office, or even as a delegated NGO service provider. We do not discuss these issues in-depth as the optimal organisational form would probably be chosen in debate by the relevant municipal council(s).
} 
recovered by the state. ${ }^{64}$ Due to its negative effects on social solidarity, support for qui tam legislation in Europe has been severely wanting. As written evidence to the UK Parliament, Tony Burchell notes that "communication from JSB Eurojust, the Vice President of the European Commission and MEPs indicated my proposal lacked the necessary quality to entice other interested parties to support strengthened whistleblowing provisions [specific qui tam].”65 National legislation establishing qui tam rewards in Macedonia will probably also be impractical in the near future - as no precedent for giving such rewards have been established in the criminal or administrative code for offering rewards to witnesses or informers. However, local-level (municipal) programmes may usefully serve as pilot projects for national laws. In this respect, municipal governments may be empowered to establish "qui tam-like" rewards as a test for future legislation. ${ }^{66}$

A number of reasons support the attempt to establish qui tam rewards at the municipal level in Macedonia. The close tie with between the increase in local revenue and qui tam rewards (offered by municipal council decree for example) makes the implementation of qui tam provisions in municipal ordinances more transparent than a similar programme adopted through legislative means (which targets national-level public services). Imagine a woman in Veles (with its population of 55,000 people and 23 member municipal council) denounces an electricity-skimming fraud. Such a denouncement saves her municipality $€ 50,000$. The local council can vote on the appropriate $20 \%$ refund (for example) to the woman. The Veles municipality gains an extra €40,000 and the lady called a "relator" in US terminology -- receives a check from the municipality for $€ 10,000$. As an open council decision, the payment receives press scrutiny (thereby decreasing the chances of payments made on the grounds of patronage or corruption within the municipal council). ${ }^{67}$ In contrast, a man who denounces a VAT fraud scheme to the Customs Administration deals in a fraud which may occur many kilometres away (or even in a foreign country) and over a long range of time. Such a national scheme would be much harder to implement.

The increased oversight and increase reversibility of ordinance-based qui tam rewards provide another benefit over a legislative based qui tam programme. If false accusations or other problems arise from the qui tam programme at the national level, legislation would be difficult and costly to revoke (requiring a vote of the Sobranie). At the municipal level, though, the ordinance can be easily rescinded or modified at a monthly council meeting. Municipal ordinances receive the oversight of the Constitutional Court and may be the subject of citizen lawsuits. Moreover, an article in the ordinance can be drafted requiring the municipal council or mayor's office to review the ordinance or to automatically place the ordinance under review if a certain number of people make complaints about municipal qui tam procedures. The ordinance can also have a termination clause (such that the ordinance will pass out of effect if the revenue collected

\footnotetext{
${ }^{64}$ Qui tam laws have a long and controversial history as qui tam rewards create incentives for untrained private citizens to engage in law enforcement activities as well as increase the number of relatively unsubstantiated accusations. For a history of qui tam legislation (and the social costs and benefits of implementing qui tam provisions), see Vermont Agency of Natural Resources V.United States Ex Rel. Stevens, 529 U.S. 765 (2000), available online.

${ }^{65}$ Memorandum by Tony Burchell to the Select Committee on European Union on the 3rd March 2008. Available online.

${ }^{66}$ See A Riley, Civil False Claims Act: Using Lincoln's Law to Protect the European Community Budget, NotTinghAm L. J. (2004). For a financial analysis of the effectiveness of qui tam provisions, see C. Broderick, Qui Tam Provisions and the Public Interest: An Empirical Analysis, ColomBiA L. REV. (2007). ${ }^{67}$ In cases where the witness or informant seeks public anonymity, the council may take its qui tam reward decision at a closed doors session.
} 
from the ordinance does not exceed costs of enforcement -- or if enough citizens object to the ordinance). ${ }^{68}$

The current legislative framework makes the payment of qui tam awards at the municipal-level relatively unclear. The Local Government Law also remains silent about the payment of discretionary awards or other payments which may serve as qui tam rewards. ${ }^{69}$ The lack of a restriction against municipally appropriated qui tam awards provides an opportunity to Macedonian municipal councillors to adopt ordinance-based qui tam provisions. Figure 17 provides a test for the legality of municipal-level qui tam rewards in Macedonia.

\section{Figure 17: A Test for the Legality of Municipal-level Qui Tam Rewards}

1. Are qui tam rewards to citizens unconstitutional (and thus likely to be overturned by the Constitutional Court)?

2. Does the municipality have the right to dedicate an appropriation for qui tam rewards during budgetary negotiations under the Budget Law?

3. Does the municipality have the right to disburse Council apportioned discretionary payments to individuals under the Budget Law?

4. Does the case involve a:

i. harm to the municipality's interests (which can be determined in financial terms and a situation in which the municipality can successfully recover damages, prevent an expenditure, or the loss of revenue) and,

ii. municipal service (building zone regulation, garbage collection, top up payments to primary schools, etc.).

The Constitutional Court may over-turn any qui tam ordinance provisions. However, three constitutional articles may come to the defence of the advocate of ordinance-based qui tam provisions. ${ }^{70}$ Qui tam (if correctly designed and implemented) upholds the constitutional values of "legal protection of property," "social justice" and of course deference to "local self-governance."71 If "property” (under article 8) includes public or state property, then qui tam provisions automatically uphold the cited constitutional value. The Constitutional Court may also interpret qui tam awards as a

\footnotetext{
${ }^{68}$ A qui tam scheme administrated by a municipal-level anti-corruption agency would also help address the issue of frivolous denouncements and complaints. Presumably, the municipal-level anti-corruption agency would be able to record individuals who make repeated claims, claims without evidence or make claims seeking revenge for some personal or professional harm. As an aside, according to theory, a penalty for frivolous complaints can be imposed which will deter such complaints. Michael (2006) treats the issue of "mechanism design" related to qui tam rewards and discusses the use of negative payments (in a game theoretic context) in order to ensure the socially optimal level of qui tam actions. See Bryane Michael, Drafting Implementing Regulations for International Anti-Corruption Conventions, QEH WORKING PAPER No.150 (2007), available online.

${ }^{69}$ In countries such as Ukraine, the creation of qui tam rewards at the municipal level present fewer legal difficulties, as Ukrainian oblasts have the right to pay discretionary "awards" upon the approval of the Oblast Council and suggest individuals for state awards. Even in Ukraine, though, such awards would require a bit of creative legal analysis.

70 For an overview of the constitutional issues involved in qui tam lawmaking (in a US context), see Evan Caminker, The Constitutionality of Qui Tam Actions, 99 YALE. L. J. 2 (1989).

${ }^{71}$ Constitution of the RePUblic OF MACEDOnia, ARTICLE 8
} 
protection of private property to the extent that corruption makes property rights over state entitlements more insecure and even comprises the theft of an individual's "property" in the form of tax payments. ${ }^{72}$ Second, Professor Kumar cogently argues that corruption represents a threat to human rights, social justice and even national sovereignty. ${ }^{73}$ Thus, in order for the Constitutional Court to rule qui tam rewards as unconstitutional, the Court would need to show that such rewards would have no impact on corruption -- as qui tam rewards (in themselves) have no (positive or negative) effect on individual liberties. Third, qui tam serves to guarantee the "the right of citizens to local self-government" (as stipulated by article 114) and thus comprises a local-governance issue instead of a law enforcement issue. The payment of qui tam awards clearly does not affect any part of the investigation or prosecution of any offence (which fall into the jurisdiction of the appropriate law enforcement agency). In this matter, the constitutional court does not need to find such payments constitutional. The Constitutional Court only needs to find that they are not unconstitutional. As such, the constitutional court need not find qui tam payments constitution - only that the Court must refrain from finding them unconstitutional.

As for getting the money to the relators, the Macedonian Budget Law (in theory) allows for the appropriation of funds for qui tam rewards. As a "budget user" (as defined in article 2.1 of the Budget Law), a municipality may propose in its budget request any foreseen or contingent expenditure (or liability), subject to Ministry of Finance and later Parliamentary approval. As qui tam provisions are always self-financed, the fiscal implications will always be positive. ${ }^{74}$ Such appropriations would consist naturally of a part of any administrative fines collected under the Anti-Corruption Law and a part of the recovery of damages in criminal and civil proceedings which are paid into the central Treasury account. Municipalities (as legal persons) may also sue their own staff and the perpetrators of corruption for damages - and these funds would be entered into the municipality's entry in the Treasury Ledger. Once the funds are appropriated, the mayor has the discretion to release these funds. ${ }^{75}$

Even though qui tam rewards may be legal, a number of issues need to be resolved at the ordinance-level. First, the ordinance should define the conditions under which a complaint, which leads to a qui tam action, may be rewarded. Obvious issues related to these conditions involve the legality of paying civil servants (as relators) who engage in whistle-blowing, the payment of joint or several qui tam rewards, maximum payments and the handling of relator confidentiality. Second, the ordinance should define municipallevel anti-corruption agencies procedures for handling of qui tam complaints (arising from the delegated authority to collect complaints on behalf of the municipality in case where State Commission jurisdiction is not involved, methods by which complaints are handled, appeal of qui tam awards in cases where the relator disagrees with his or her award and other issues). Third, ordinance-based provisions should be in place for the review of the handling of qui tam cases (by both the municipal-level anti-corruption agency and by municipal councils which both regulate the agencies' work and make qui tam awards). Municipal ordinances can resolve these and other issues.

\footnotetext{
${ }^{72}$ CONSTITUTION OF THE REPUBLIC OF MACEDONIA, ARTICLE 33 [“"everyone...is obliged to pay tax and other public contributions, as well as to share in the discharge of public expenditure in a manner determined by law."]

${ }^{73}$ See C Kumar, Corruption, Human Rights, and Devlopment: Sovereignty and State Capacity to Promote Good Governance, 99 Am. SOC’Y INT’L L. PROC. 416 (2005).

${ }^{74}$ Article 26 of the Budget Law imposes on budget users the requirement to provide an assessment of the fiscal impact of any budget request.

${ }^{75}$ Part 4 of the test referred to in Figure 17 follows relatively automatically from the prosecution for corruption. Namely, if the offence concerned a municipal service, then part 4 of the test is automatically satisfied.
} 


\section{Toward a Model Anti-Corruption Ordinance}

Numerous complexities arise during the drafting of an anti-corruption ordinance. The supremacy of legislation, and a wide variety of other laws, complicates significantly ordinance drafting (as does the numerous potential conflict of laws which may arise within the municipality, between municipalities and with executive agency regulations). Unlike in the United States (where $10^{\text {th }}$ Amendment rights devolve power to the people) or with the EU Treaty doctrine of subsidiarity, in Macedonia such sovereignty remains expressed through national institutions. Municipalities "get the scraps and left overs" of state authority. ${ }^{76}$ Nevertheless, a number of provisions may be drafted into a municipal-level anti-corruption ordinance (and Figure 18 provides a draft "model” ordinance). ${ }^{77}$

An anti-corruption ordinance needs to define the legislatively mandated, as well as devolved authority, of the municipality for fighting corruption (which will be useful later in the ordinance). Devolved authorities may include (depending on the State Commission's interpretation): giving opinions about laws, proposals for supervising political parties, proposals for supervising NGOs, consideration of conflict of interest cases, supervision of changes in wealth of local officials, co-operation with other state agencies, and providing education about preventing and fighting corruption. The owncompetencies of such anti-corruption agencies (given by the subscriber municipalities themselves) include the handling of non-criminal disciplinary proceedings, the conduct of corruption risk audits and creation of risk profiles of staff (including integrity probes) as well as conduct of service delivery surveys. Competencies (which remain to be defined) include the grant of positive administrative silence, the setting up of a qui tam reward scheme, the putting in place of additional safeguards related to public procurement, and the grant of certiorari relief from local service delivery related ordinances.

With the municipality's legal competencies established, the anti-corruption ordinance can assign those competencies to the entity best able to execute them. As previously discussed, a (inter-municipal) anti-corruption agency may serve as an organisational entity best able to provide efficiency and economy. As multiple municipalities are involved, the ordinance would define the procedures for co-ordinating and negotiating with other municipalities and the grant of jurisdiction over municipal-level public services operating in the municipality. The composition of the agency would be described, the method of employment or secondment defined, and the physical office would be agreed upon.

Relations between the municipal-level anti-corruption agency and the municipal authorities (with mayors and particularly the councils of the subscriber municipalities) would also need to be defined. As the municipal-level anti-corruption agency has no authority of its own, the ordinance must define the anti-corruption agency's relations with each of its member municipalities. The ordinance would also define the procedure to follow for putting anti-corruption agency items on the council's meeting agenda - as well as procedures for raising issues or requests to the shared municipal anti-corruption agency

\footnotetext{
${ }^{76}$ As in interesting side issue, Macedonia has ratified the European Charter of Local Self-Government (CETS 122) which states in article 4/3 that "Public responsibilities shall generally be exercised, in preference, by those authorities which are closest to the citizen. Allocation of responsibility to another authority should weigh up the extent and nature of the task and requirements of efficiency and economy." The legal issues involved in an international treaty which helps guarantee the supremacy of local legal autonomy shall certain provoke debate in Macedonia for years to come.

${ }^{77}$ We discuss the main or more controversial issues in the "model” ordinance and omit a discussion of several of the chapters to save space.
} 
during council meetings. The agency's authority to act in municipalities other than the one which houses (or hosts) the physical offices of the agency would also be established. 


\section{Figure 18: Draft Anti-Corruption Municipal Ordinance}

\section{GENERAL PROVISIONS}

Chapter 1 Definitions

Chapter 2: Competencies of the Municipality to Fight Corruption in Public Services

Chapter 3: Establishment, Mandate, Composition and Premises of Agency

Chapter 4: Agency-Council Relations

Chapter 5: Funding of Regional Anti-Corruption Agency

\section{OPERATIONAL PROVISIONS: DELEGATED COMPETENCIES}

Chapter 6: Provisions for Legal Review (Legislation, Regulations and Ordinances)

Chapter 7: Assistance with the Supervision of Local Elections

Chapter 8: Local Monitoring of Conflict of Interest

Chapter 9: Delegated Work on Asset Declarations

Chapter 10: Representations to State Agencies

Chapter 11: Responsibilities for Public Education and Awareness Raising

\section{OPERATIONAL PROVISIONS: OWN COMPETENCIES}

Chapter 12: Handling of Non-Criminal Disciplinary Proceedings in the Regulation or Provision of Public Services

Chapter 13: Creation, Updating and Maintenance of Corruption Risk Profiles and Procedures for Corruption Risk Audit (including integrity probes)

Chapter 14: Oversight of Service Delivery Scorecards

Chapter 15: Procedures for Working with NGOs

\section{REGULATORY PROVISIONS}

Chapter 16: Applicability of Positive Administrative Silence

Chapter 17: Rules of the Qui Tam Reward Scheme

Chapter 18: Additional Safeguards Related to Public Procurement

Chapter 19: Grant of certiorari Relief from Local Service Delivery Related Ordinances

Chapter 20: Representations in Administrative, Civil and Criminal Cases

\section{FINAL DISPOSITIONS}

Chapter 21: Termination and Sunset Clause and Severability Clause

Chapter 22: Provisions Related to ZELS Co-ordination of Final Model Ordinance and Requirement (Procedures) for Public Dialogue on Present Ordinance

Chapter 23: Executing Provisions

The funding of such municipal-level anti-corruption agencies represents one of the most important and difficult questions related to ordinance-based anti-corruption work. As mentioned previously, a budgetary appropriation would need to be made for qui tam provisions. However, the municipality would also need to apportion a pro-rata share for its subscription for "core" funding for the agency. While the easiest funding scheme would be based on the municipality's population or share of national GDP, such a funding arrangement would severely dampen any performance incentives. Funding should be 
based on either the level of corruption in the municipality or the success of local corruption fighters in reducing corruption. ${ }^{78}$

Legal review represents one of the most important non-operational competencies which can be devolved from the State Commission. Such review consists of reviewing legislation and executive agency regulations on behalf of the State Commission (as required given their limited manpower). Such review more usefully may consist of council decisions and ordinances as well as internal instructions of the managing committees of the public enterprises which provide municipal-level public services. Naturally, the municipal-level anti-corruption agency would need to use risk-profiling and sample municipal-level instructions and ordinances to review. Furthermore, the anti-corruption agency can recommend that municipal councils give certiorari relief from local service delivery related-ordinances in cases where the regulation poses a high corruption risk.

Assistance with the supervision of local elections represents another area of delegated responsibility which municipal-level anti-corruption agencies could assume. In Macedonia, counsellors from each of the 84 municipalities may be elected from roughly 60 political parties. The State Commission will have tremendous difficulty monitoring the 24 provisions of the Anti-Corruption Law (related to political party corruption) of these potentially thousands of candidates to municipal elections. ${ }^{79}$ Article 45 of the Law on Local Elections notes that, "the financial report [of the campaign] shall be submitted to the municipal council and the Council of the City of Skopje no later than 3 months after the elections are finished." ${ }^{80}$ As a result, the Council of the City of Skopje can easily receive over 1,000 campaign reports (if reported for each candidate)! Even over one of those reports, surveillance would be difficult - given the complexity of the revenue and expense figures provided. For example, article 8 notes that "a political party, trade union, or association of citizens may not collect funds in cash from unidentified sources for financing its activity.” Yet, for the simplest accounts, an auditor may need hundreds of hours to collect enough evidence to show that an expense had been paid in cash (and from a source the accounts do not identify).

Municipal-ordinance drafting may also usefully define the responsibilities of the municipal-level anti-corruption agency in monitoring conflicts of interests. Such monitoring may include supervision over potential conflicts of interest among municipal employees and the employees of the 70 public enterprises which operate in the municipalities. Municipal-level anti-corruption agency work may also include helping the State Commission to collect conflict of interest declarations from these employees, holding declarations, and helping with the conduct of random audits of declared interests (as well as the random audit of municipal employees for undeclared interests).

Such ordinances may also clarify the procedures to follow for delegated work on asset declarations. Municipal-level anti-corruption agencies may help the State Commission collect the large number of asset declarations (of the over 17,000 public

\footnotetext{
${ }^{78}$ For the economic analysis of the optimal funding of such anti-corruption agencies, see Michael, supra note 68. A system of internal budgets can also be used such that each municipalities could draw on the agency for services at an internal price. However, such a system would be inferior to the "performancebased budgeting” scheme previously proposed.

${ }^{79}$ Chapter II of the Anti-Corruption Law deals exclusively with the prevention of political corruption while Chapter III deals with the prevention of corruption in "public mandates" (addressing political figures as both candidates and as public officials after election).

${ }^{80}$ Law on Local Elections, available online.
} 
officials working within the "colour of the law" of Macedonian municipal government). ${ }^{81}$ The ordinance may also define procedures for the collection of such asset declarations and the local-level processing of any information before being transmitted to the State Commission. The local anti-corruption agencies could also usefully provide counselling on filling in asset declarations and monitoring any significant changes to municipal public officials' wealth. Article 34 of the Conflict of Interest Law imposes a relatively heavy regulatory burden on the State Commission. The article covers any "elected or appointed civil servant, official and responsible person in a public enterprise or other juridical person managing state capital...[and] property of a member of his family." 82 Members of his or her family may be interpreted in the law as a "person in close affiliation" -- and thus persons in wedlock or a non-marital relationship with the official, his/her lineal blood relatives and lateral relative by sanguinity up to the fourth degree, adoptive parent or adoptee, in-laws conclusive with the second degree of relation." ${ }^{83}$ Significant changes, according to the law, are "worth more than the amount of twenty average salaries in the economy in the previous three-month period." 84

Related to the municipalities own competencies, the handling of non-criminal disciplinary proceedings represents an important area of municipal-level anti-corruption agency work. In many cases, the police do not investigate cases of alleged or suspected corruption. Instead of criminal investigation, for minor corruption offences, the municipal agency (or public enterprise involved) may initiate its own disciplinary procedures. A municipal-level anti-corruption ordinance may treat the procedures to follow, both in the internal investigation (in non-criminal cases) as well as procedures to follow in aid of criminal investigators. ${ }^{85}$

Corruption-risk profiles and risk audits comprise another area of work for municipal-level anti-corruption agencies. Risk profiling consists of assessing the probability of a municipal official taking part in corrupt activities. Increasingly, agencies are assigning risk probability to individuals or the offices they occupy. In some cases, these profiles are used to guide risk audits - either performance or compliance audits. ${ }^{86}$ Municipal governments have the duty to establish risk profiles and conduct regular corruption risk audits in order to indemnify themselves (as legal persons) for joint liability if their staff are found guilty of corruption, to protect their own financial interests and to

\footnotetext{
${ }^{81}$ The estimate of the number of municipal-level civil servants represents best-guess based on World Bank and local government statistics.

${ }^{82}$ Conflict of Interest Law, at article 34.

${ }^{83} \mathrm{Id}$., art. 3. Without exaggerating, given a population of 2 million people, article 3 requires that the government receive information about the assets of roughly $15 \%$ of the entire Macedonian population! The World Bank reports a civil servant base of roughly 20,000 people. Assuming each of those individuals participates in one monogamous relationship and that both individuals in the relationship have 2 surviving parents, 2 siblings and those siblings have either 2 parents or children of asset-holding age, the government should keep information about the assets of roughly 320,000 individuals.

${ }^{84} \mathrm{Id}$., at 34 . At the time of this writing, such a change is wealth equals roughly $€ 5,000$ (a month's rent in a large European capitol).

${ }^{85}$ Around the world, criminal investigators are increasingly relying on regulatory investigations (and relying on the legal person's own internal investigation) to provide prosecutors with initial evidence about whether to take the case forward. See M Shabat, SEC Regulation of Attorneys under the Foreign Corrupt Practices Act: Decisions on Efficiency and their Role in International Anti-Bribery Efforts, 20 U. PA. J. INT'L ECON. L. 987 (1999) [also provides a particularly interesting discussion about the role of attorney-client privilege during internal investigations in a US context].

${ }^{86}$ For more on the corruption risk audit, see MUHAMMAD KHAN, A PRACTITIONER'S GUIDE TO CORRUPTION Auditing: The Role of InTERnAl Auditors AND GOVERnMENT Auditors (2005).
} 
reduce the liability for senior management (as natural persons) for the misdeeds of their staff. $^{87}$

Severability will represent an important issue in the new legal area of anticorruption ordinance drafting. The Macedonian Constitutional Court may disagree with the legal analysis provided in this article and strike down one or more of the provisions in the ordinance. The severability clause should keep the rest of the ordinance intact as well as preferably define procedures to follow if any particular provision (such as the qui tam reward scheme or the grant of positive administrative silence rights) are deemed unconstitutional or ultra vires to the municipal council.

As previously mentioned, the independent adoption of 84 different ordinances would be impractical. In practice, a likely diffusion mechanism for anti-corruption ordinance-making in Macedonia would be the ZELS or the Association of the Units of Local Self-Government of the Republic of Macedonia. Discussion (and possible promotion) of such a model clearly falls in the ZELS's charter of "maint[aining], develop[ing], and strengthening...efficient and effective local self-government" (article 6.1.2). ${ }^{88}$ The ZELS would likely promulgate the anti-corruption model ordinance by "organizing conferences, seminars, consultations, workshops, sessions, fairs, campaigns, etc.” (as required by article 7.1.1 of its charter).

As part of its legally required mandate, the ordinance should have a regulatory impact assessment. ${ }^{89}$ According to economic estimates, corruption involving municipal services in Macedonia is likely to involve $€ 2$ million. ${ }^{90}$ The ordinance should improve the State Commission's audit capabilities and improve service provision (by incentives offered through qui tam rewards and scorecard results). If such activities reduce corruption by $10 \%$, then municipalities will save $€ 200,000$ over the next 2 years. In contrast, the costs of the adoption of the model ordinance (and the establishment of the three municipal-level anti-corruption agencies) would involve $€ 37,100 .{ }^{91}$ As a result, Macedonian welfare would increase by $€ 162,900$.

Figure 19: Regulatory Impact Assessment Costs of Anti-Corruption Municipal Ordinance

\begin{tabular}{|l|l|l|l|l|}
\hline & $\begin{array}{l}\text { days per } \\
\text { man }\end{array}$ & $\begin{array}{l}\text { men } \\
\text { number }\end{array}$ & $\begin{array}{l}\text { total man } \\
\text { days }\end{array}$ & Total Cost \\
\hline $\begin{array}{l}\text { Establishment of 3 municipal level } \\
\text { anti-corruption agencies }\end{array}$ & 30 & 9 (max) & 270 & $€ 5,400$ \\
\hline assistance with 300 scorecards & 60 & 3 & 180 & $€ 3,600$ \\
\hline $\begin{array}{l}\text { review of 500 ordinances or } \\
\text { instructions }\end{array}$ & 60 & 3 & 180 & $€ 3,600$ \\
\hline assistance with asset declarations & 40 & 2 & 80 & $€ 1,600$ \\
\hline
\end{tabular}

\footnotetext{
${ }^{87}$ For a review of some of the law in this area, see R. Evans, Damages for Unlawful Administrative Action: the Remedy for Misfeasance in Public Office, 4 InT'L \& CoMP. L. Q. 31 (1982)

${ }^{88}$ Bylaws of the Association of the Units of Local Self-Government, available online.

${ }^{89}$ The legislative requirement for Regulatory Impact Analysis (or RIA) for Macedonia is discussed in OECD, Review of Regulatory Governance in South East Europe, Available online.

90 The calculation of the probable economic value of corruption in a country requires a range of assumptions and estimates (which we do not discuss for reasons of space). For a country with a GDP of \$8 billion and a ranking of 84 out of 179 countries on Transparency International's Corruption Perceptions Index, an estimate of .0025\% of GDP involved in bribes does not seem like an excessively high estimate of the value of bribery in Macedonia. For more on the economic calculation of corruption, see SUSAN ROSE-ACKERMAN, supra note 14 or Bryane Michael and Mariya Polner, supra note 9.

91 The relative low cost stems from Macedonia's low public sector wage structure.
} 


\begin{tabular}{|l|l|l|l|l|}
\hline admin of qui tam scheme & 60 & 2 & 120 & $€ 2,400$ \\
\hline advising government officials & 30 & 9 & 270 & $€ 5,400$ \\
\hline counselling municipal service users & 60 & 9 & 540 & $€ 10,800$ \\
\hline anti-corruption publicity & 40 & 2 & 80 & $€ 1,600$ \\
\hline ZELS's work & 45 & 3 & 135 & $€ 2,700$ \\
\hline $\begin{array}{l}\text { other agency's work in adjusting to } \\
\text { model ordinance }\end{array}$ & 2 & 200 & 400 & \\
\hline Totals & $\mathbf{3 8 7}$ & $\mathbf{2 4 0}$ & $\mathbf{2 1 7 5}$ & $€ \mathbf{3 7 , 1 0 0}$ \\
\hline
\end{tabular}

* The calculations in the Figure assumes $€ 20$ euros a day salary on average resulting in the relatively low cost of the anti-corruption ordinance-making programme by international standards.

\section{Conclusions and Future Research Questions}

The Macedonian fight against corruption could usefully benefit from ordinance design which leads to the establishment of municipal-level anti-corruption agencies. Such anti-corruption agencies -- representing possibly the first example of such agencies covering an entire nation-state -- could increase welfare in the first year of their operation by $€ 162,900$ by significantly contributing to the work of the State Commission for the Prevention of Corruption.

The most important future research question revolves around the authority of municipalities to engage in anti-corruption law-making -- given the tension between decentralisation (which favours municipal-level anti-corruption work) and adoption of the international anti-corruption conventions (which tend toward nationally-centralised agencies and the strengthening of the central services such as the Ministry of Interior, Ministry of Justice and other state ministries). Given the declining interest in municipal anti-corruption programmes (and increasing interest in international anti-corruption conventions), this paper hopes to put municipal government back into the research arena.

The secondary future research question revolves, naturally, around the effectiveness of such municipal anti-corruption programmes. Despite over 8 years of work on municipal anti-corruption programmes (mostly inspired by Klitgaard et al.'s work), academics and practitioners have relatively few success stories based on these authors' example. If the Macedonia government launches an ordinance-based anti-corruption programme, the results may provide data for future research to determine whether donor agencies - like the World Bank and USAID in particular - should continue their anticorruption work with municipalities. . 